\title{
Emotional Intelligence a Critical Factor in Organizational Performance
}

\author{
Neeta Baporikar, Namibia University of Science and Technology, Namibia \& University of Pune, India \\ D https://orcid.org/0000-0003-0676-9913
}

\begin{abstract}
The objective of this study is to understand how employee EI is a critical factor for improved organizational performance. Adopting a qualitative approach with a case study research design, a sample of 40 employees was selected from the organization; data collection was done through a questionnaire after pilot testing. An analysis is done using SPSS, within an interpretative research paradigm using thematic analyses. Findings reflect that understanding and knowledge on EI and its influence on the performance may add value to the organization as employees become aware of the best practices and contribute better for organizational performance. Further, it was also noted that EI is a significant predictor of job and organizational performance only if it is advocated and spearheaded through individual performance classified into the task and contextual performance.
\end{abstract}

\section{KEYWORDS}

Application, Belief, Culture, Excellence, Motivation, Organization, Value-Addition

\section{INTRODUCTION}

Despite the growing interest in recent years in emotional intelligence (EI) within the managerial literature, too little has been written about EI within state-owned or the public sector. This is surprising in light of new public management voices that stress flexibility, responsiveness, and a focus on the needs and demands of citizens (Vigoda-Gadot \& Meisler, 2010) particularly for creating excellence and enhancing performance. Creating a culture of excellence in organizational performance is dependent on several factors, like government policies, organizational culture, effective management, and better human resources management which necessitate dealing with EI. EI or individual emotional quotient has a direct relationship to work and organizational effectiveness and in particular to excellence in jobs of all kinds (Goleman, 1985). Wider areas of intelligence enable or dictate how successful employees are toughness, determination, and vision help. But emotional intelligence, often measured as an emotional intelligence quotient, or EQ, is more and more relevant to important work-related outcomes such as individual performance, organizational productivity (Serrat, 2017). EI therefore is an increasingly important consideration in human resource planning, job profiling, recruitment interviewing and selection, learning and development, and client relations and customer service, among others. Further, EI has been identified as a key competency for successful organizational performance 
in life as well as in the workplace. Other studies also suggest that there is a relationship between high absenteeism, burnout, high turnover, and EI in turn can be linked to organizational performance.

Over the years, researchers have become fully aware that cognitive intelligence is not sufficient to measure organizational performance. They discern another type of intelligence which is called EI. The term "EI" was first coined by Mayer and Salovey (1990) which calls attention to one's capacity to be conscious, process and regulate emotional information correctly and successfully, both within oneself and in others and to use this knowledge to guide one's thinking and actions and to have an effect on those of others. Bar-On (1997) posits that people with higher EI perform better than those with lower EI in life overall, regardless of their cognitive intelligence. Goleman, (1995) also states that. EI has been recognizing as a fundamental competency for successful performance in life as well as in the workplace.

According to Pekaar, Bakker, van der Linden, \& Born (2018), in previous research studies EI has been associated with both intrapersonal and interpersonal benefits, including mental and physical health, work organizational performance, and the quality of social interactions. Intrapersonal refers to the emotions of the self and the ability to remain emotionally and physically healthy, productive and fulfilled, while interpersonal relates to understanding how other people's emotions and learning effectively interact to enjoy and benefit from having positive social relationships. Creating a culture of excellence in an organization is dependent on several factors, like government policies, organizational culture, effective management, and better human resources management, which necessitate dealing with EI. Moreover, the work conducted in most organizations has changed dramatically in the last 20 years. Of course, there are now fewer levels of management and management styles are less autocratic. But there has also been a decided move toward knowledge and team-based, client-oriented jobs so that individuals generally have more autonomy, even at the lower levels of organizations. Since modern organizations always look to improve performance, they recognize that objective, measurable benefits can be derived from higher emotional intelligence. To name a few, these include increased sales, better recruitment and retention, and more effective leadership (Serrat, 2017). Because of its impact on job performance, decision-making processes, and interpersonal relations, EI is highly significant for organizational psychology, especially in personnel issues (such as recruitment or promotion) and career counseling.

According to Goleman (2001), EI is critical in decision making and plays a significant role in shaping people's behaviors (which result in task performance). Emotions have the power to motivate, regulate one's actions, and control one (Brown, Gregory- Currran \& Smith, 2003). Understanding such phenomena is therefore critical because of their significant implications. Further EI relates to contextual and task performance on the job. Most EI facets relate with job performance in a nonlinear manner (Bozionelos \& Singh, 2017). The National Housing Enterprise (NHE) is a state-owned company, under the Ministry of Urban and Rural Development, $100 \%$ owned by the government of Namibia. The footprints of NHE are seen in 5 regions, such as Khomas, Karas, Erongo, Oshana and Kavango West apart from the Head office in Windhoek. Therefore, based on Goleman's theory of EI adopting a qualitative, descriptive methodology, the main objective of this study is to investigate the employee EI as a critical factor for organizational improved performance in national housing enterprise (NHE) at Namibia.

\section{Research Methodology}

This study made use of the qualitative methodology with interpretivist paradigm. The choice of the method was due to the objective of the study and as the research variables were qualitative in nature. Furthermore, a qualitative design was used because the study involved the perceptions, viewpoints and opinions.

- Population: 130 employees.

- Sampling Method and Size: Adopting convenience sampling 40 employees constituted the sample size. 
- Data Collection: Done through primary source and secondary source. A well-structured questionnaire to collect primary data was employed with closed-ended and open-ended questions. Secondary sources include published reports, articles and documents.

- Pilot Study: Further a pilot study was conducted by administering the questionnaire to four employees. The researcher administered the questionnaire after reading the instructions and confidentiality statement. There were no uncertainties experienced and it took about 40 minutes to complete the questionnaires. The survey was completed without any problem, confirming that the questionnaire was well drafted.

- Data Analysis and Presentation: The questionnaires were analyzed using the Likert scale by adopting a thematic analysis approach to support the qualitative research method adopted. The thematic data analysis technique was chosen because of the type of data that was collected from the respondents which was thematic in nature. The themes of the collected data formed patterns which are common across and important to the elucidation of research objectives, and question as observed by Braun and Clarke, (2006). Tables, graphs, charts and thematic contents are used to analyze and present data.

\section{LITERATURE REVIEW}

Intelligence is a harmonious problem solving behavior toward facilitating realization of applied goals and harmonious growth (Yazdani \& Riahi, 2010). The term and its exact meaning was an area of debate among psychologists and philosophers for over one century. According to the Oxford Dictionary, intelligence is any stimulation and disturbance in brain, feeling, and love, any strong and exited mental mode. The term is used to highlight a feeling, thought, and mental and biological mode regarding a specific range of interests that makes the individual engage in an activity. Taking combinations, variety, and nuance differences into account, there are hundreds of types of emotions. In fact, there are countless variant of emotions without specific term (Yazdani \& Riahi, 2010).

Emotional intelligence (EI) is the ability to sense, understand, and successfully apply the influence and insight of emotions as a source of human energy, information, connection, and influence. This points to the fact that EI is a psychological competence, which takes cognizance of emotions to enhance human relationships. In other words, EI is the skill to perceive and constructively act on both one's own emotions and the feelings of others. EI is been described at the most common level, as skills to identify and regulate emotions in ourselves and others (Goleman, 2001). According to Mayer and Salovey (1997) EI is the ability to perceive accurately, appraise, and express emotion; the ability to access and/or generate feelings when they facilitate thought. Averill (2007) believed that people with strong emotional intelligence are able to comprehend the beliefs and rules that give meaning to an emotion. They are also very good at evaluating the situation and express their emotions skillfully. According to Mandell and Phewani (2003), EI refers to a set of abilities that involves perceiving and reasoning abstractly with information that emerges from feelings. Besides, Thorndike, a psychologist establishes that EI has several types of intelligence, one type being the ability to understand and manage human beings and to act intelligently in human relations (Thorndike, 1920).

Thus, EI is seen as critical ingredient that affects people's social life and direct behaviors. Similarly, the most shared components found in EI areas: Self-Awareness, Self-Management, Social Awareness, and Relationship management. These constructs are shared by all main theories of EI. EI is sometimes referred to as emotional quotient or emotional literacy. Mayer and Salovey (1997) identified the following four areas of EI: identifying emotions, understanding emotions, using emotions, and managing emotions. Weisinger (1998) states that EI has four dimensions namely to realize, identify emotions, and comprehend accurately, to produce emotions for understanding one's self and others, to understand emotions and that information comes from emotions and to regulate emotions for emotional and intellectual development. Research on the phenomenon of EI began in the early 20th Century. Many authors have attempted to list the historical background of research on 
EI (Bharwaney, 2011). As primary motivating forces, emotions are physical sensations that drive a person to act in a certain way. They are forces by which the body and mind communicate. Emotions are constantly changing and moving. Emotions are the connection between the body and the mind as they connect human thinking with health. On the other hand, intelligence is referred to as a set of mental abilities and skills that a person possesses to make a difference in life.

\section{Significance of EI}

Employees are contemplated as an indispensable pillar of the organization. Their attitudes and behaviors at the workplace have a drastic effect on organizational performance and success (Baporikar, 2020a). Employees' emotional intelligence at the workplace has immense importance in shaping their behaviors and attitudes. On the other hand, behaviors and attitudes plummet towards negativity in the polluted environment in the organization (Ahmad, Nisar, Othman \& Kamil, 2017).

Way back Darwin, (1872), states that EI is essential for survival, He posits to understand the physical, social and mental impact that negative emotions have on your body, mind, relationships, and capability to pursue and achieve goals one must have high levels of EI. Darwin also states that people with a high level of EI are more successful in their profession; they also are in good physical condition, cheerful and enjoy better relationships with others. Those with a high level of EI tend to have a healthy balance of feelings like motivation, attention, contentment, consciousness, self-control, independence, gratitude, connection, friendship, and desire. Those with a lower level of EI tend to feel more: fear, frustration, guilt, resentment, anger, disappointment, and failure.

Moreover, individuals with higher EI are better equipped to work within teams, manage stress, and deal with change constructively, thus empowering them to be more efficiently pursuing their business objectives and goals. Goleman (1995) in the same thinking articulate that EI can be learned or improved. When EI is been learned or improved it can produce significant benefits, from personal contentment and well-being to elevated success in a business context. Whereas, Bar-On (1997) posits that people with higher EI tend to perform better than those with lower EI in life overall, regardless of intelligence quotient (IQ). A person with high EI is better prepared to manage conflict, communicate without descending to confront, and build meaningful relationships given their ability to identify, manage, and understand emotions (Lopes, 2005). Further, EI is a driver of effective communication within teams, hence EI positively affects the quality of communication. Those with low levels of EI may increase conflict and react unnecessarily in stress full situations while individuals with higher EI will have the ability and be also able to communicate effectively without confrontation (Cherniss, 2015).

\section{Significance of El in the Workplace}

Nowadays, nobody doubts about the importance and gravity of human force in organizations. While capital and machineries were once considered as the main resources today, human resource and mainly those with high emotional capacity is considered the as a critical resource. On the other hand, there are varieties of factors that influence organizational performance. Having these factors recognized and examined is of great help in both the improvement of organizational activities and the realization of organizational goals. Performance is one of these factors as it means competitive advantage (Yazdani \& Riahi, 2010).

Systems approach views organizations as a set of interdependent fundamentals and work performance comprising of input, process, and output, which are influenced by the external environment (Gryn, 2010). Job performance is based on information of these changeable components namely capacity which consists of skills and knowledge, motivation and willingness, and external factors like work volume tools and climate (Baporikar, 2019). Figure 1 provides the organizational performance as an open system.

Once an organization brings in resources from the external environment, these are processed through work into the final output, be it services or products. Each system is influenced by numerous factors, such as the interdependence between the company and its environment. Some of the factors 

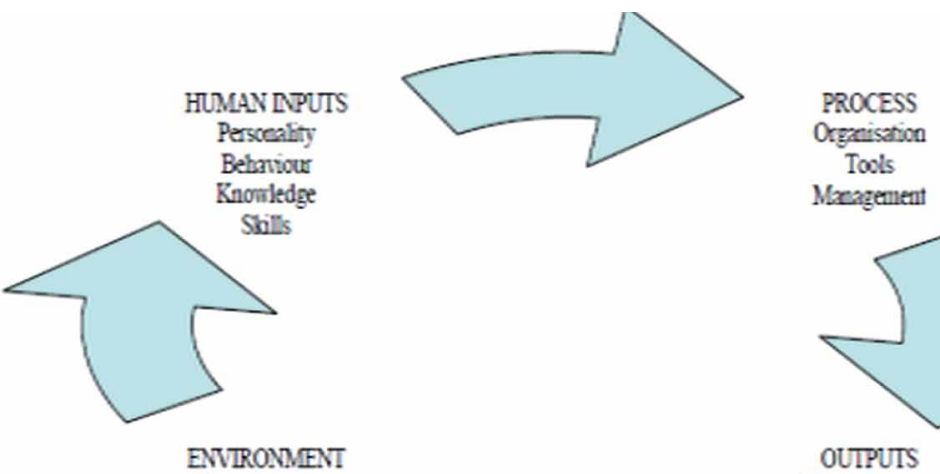

Extemal Factors
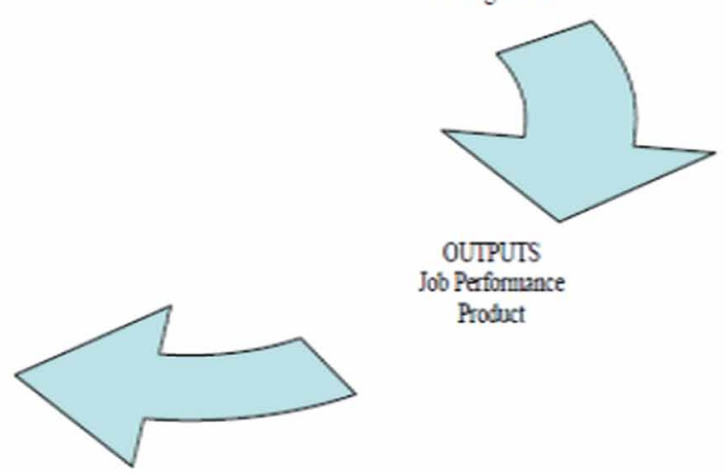

OUTPUTS

Job Performance

Protuct

\section{Source: Adopted from Ivancevich, Konopaske \& Matteson (2005)}

that influence the system are competition, economic situation, employees' personality, and skills, interdependence, and opportunities (Baporikar, 2020b). Moreover, to measure organizational performance, one needs performance criteria. These organizational performance criteria need to be developed by adopting a holistic approach - that is, when measuring organizational performance one needs to look at the whole system.

\section{El and Productivity}

The success in working and in overall working performance is not depending only on professional knowledge and the level of IQ of employees and managers, but also very important impact is having the level of emotional intelligence (Rexhepi \& Berisha, 2017). Organizational performance is a role of knowledge, expertise, potential, and motivations (Rangriz and Mehrabi, 2010). It can be stated that EI influences organizational performance and productivity. High EI also affects all aspects of management (Jordan, Ashkanasy \& Hartel, 2002). Brown et al., (1997) also agree that EI is a very powerful ability that can affect behavior and organizational performance positively. EI enriches work-life and simultaneously affects job performance positively. Job satisfaction consists of work and work conditions and the pleasure one feels. Satisfaction will result in increased organizational performance when organizational efforts are aimed at improving employee satisfaction. (Bowling, 2007). Thus, EI is credible driver of superior organizational performance. Cross and Lynch (1995: cited in Gryn, 2010) developed the pyramid of work and performance to link organizational strategy and operations and provided a set of objectives that are filtered from the bottom upwards. The model is based on the assumption that strategy and operations are linked by the conversion of objectives from the top in achieving the final vision and implementation of appropriate measurement tools from the bottom up. Figure 2 reflects the linkage of the pyramid of work and performance to organizational strategy and operations.

\section{Role of El in HRM}

Human Resource Management (HRM)'s main responsibility is to get competent people, train them, and getting them to perform at high levels. It involves the productive use of people in achieving 


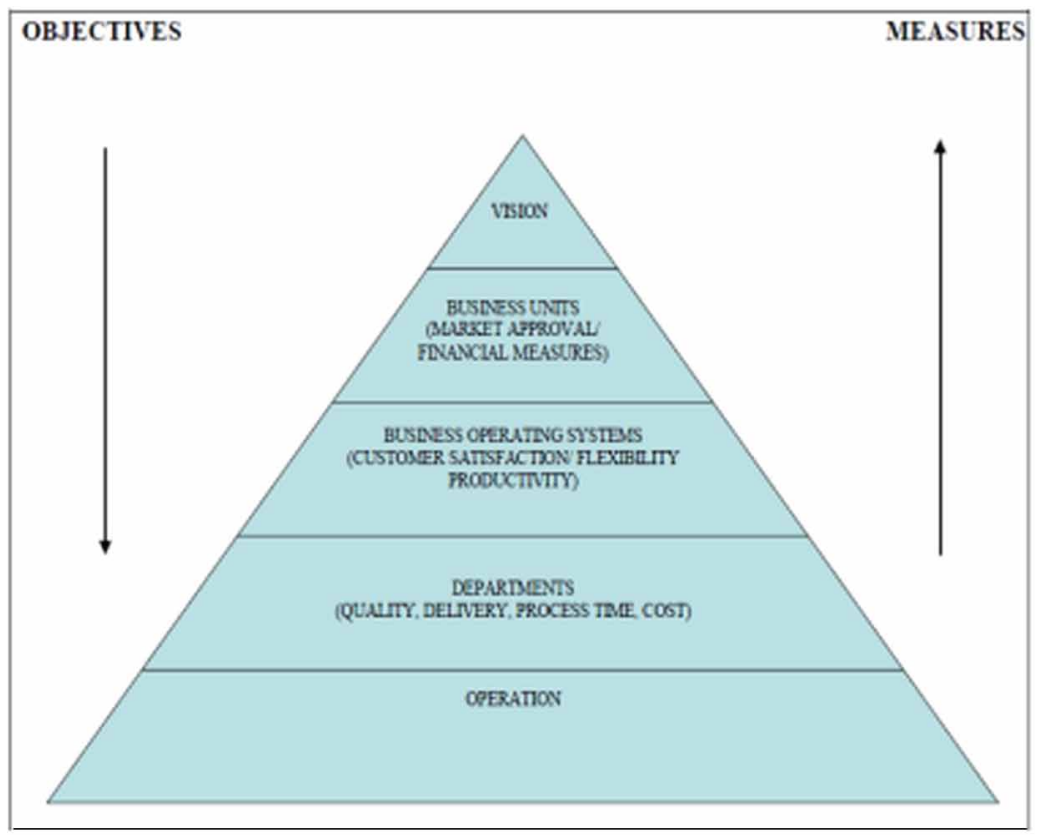

Source: Adapted from Cross \& Lynch (1995)

organizational strategic goals (Stone, 2008). However, most organizations largely focus on an applicant's educational qualification, experience, ability, and domain in their Human Resource (HR) selection process, which is the conventional method. Cherniss (2001) posits that with the help of HR functions as recruitment, selection, training, and development, EI can be incorporated in the organization thus leading to organizational effectiveness. In the same vein, Brown (2005) asserts that an HR practitioner's role is to develop an individual's skills, ability, and traits to empower them to recognize, manage and regulate their emotions. Further, when EI is developed in individual's it will be of assistance to the leader and team and help in collective performance (Baporikar, 2018; 2017a). Cherniss and Goleman (2001) postulate that coaching and mentoring is the most influential theme in developing EI and they also assert to develop personal and social-emotional competencies one can use the modeling approach person. People learn in part by observing and by emulating peers and other role models. According to Boyatizis (1982), various types of jobs need various emotional expertise. Salespeople's emotional expertise is influence, empathy whereas Debtors Agent requires emotional expertise as service orientation and empathy. Bhatacharya \& Senguta (2007) state that EI is key to differentiates between the excellent and average executive.

\section{El at Work}

Human relationship management is the ability to understand others and relationships (Torubelli, \& Adeoye, 2011). Higgs (2004) agrees that EI is about own emotion, be thoughtful, handle relationships effectively, and being able to motivate ourselves to get jobs done. Goleman (2014), a further emphasis that first-line supervisors who appreciate and employ their EI in the workplace are more likely to retain their staff, enjoy greater collaboration and commitment supports this. Carmeli and Josman (2006) suggest there is a possible connection between EI and positive collective organizational performance in the workplace. Bar-On (1997) referred to EI as non-cognitive capabilities, competencies, and 
skills, which help an individual to become more efficient in the workplace. Cherniss (2001) in the same thinking established that EI uses individual feelings and emotions to solve problems. Briner (1999) asserts that interest in emotions at work has heightened as most organizations are operating in the service industry. Hochschild's (1983) theories for a new concept "emotional labor" where she postulates that a large number of jobs demands physical and mental labor but some, require emotional labor. Goleman (1995), claimed that IQ cognitive ability contributes to around $20 \%$ towards life success and the $80 \%$ accounts directly to EI. Table 1 lists 25 social competencies from emotional awareness to team capabilities which lead to success at work.

Thus, employees with high EI communicate better their ideas, intentions, and goals. They are more confident and sensitive and are more observant and know their strengths and weaknesses as well as their teams, which helps to build supportive conditions that increase organizational commitment which in turn leads to success (Furnham, 2012).

\section{El and Organizational Performance}

Performance is the efficient and effective use of one's skills whereas collective organizational work performance is the capability of employees to use their skills to accomplish the goals of the organization "Job organizational performance may be conceptualized in terms of three areas restated as follows: First, an employee has to engage in a specific behavior or certain behaviors relevant to the job performance criteria. Second, the behavior or behaviors that an employee engages in should lead to the accomplishment of relevant tasks. Third, the relevant tasks should contribute to the realization of value for the organization" (Dhliwayo, 2018, p. 69).

On the other hand, the contextual organizational performance consists of behavior that does not directly contribute to organizational performance but supports the organizational, societal, and mental environment (Sonnentag, Volmer and Spychala, 2008). It is known that emotions may interfere and twist human decisions and judgment (Shafir \& LeBoeuf, 2002), as well as critical analysis and logic (Oaksford, Morris, Grainger, \& Williams, 1996). Hence, some emotion profiles will be beneficial in certain situations or circumstances and not in other situations (Rushton, Murray, \& Paunonen, 1983) and individual EI profiles will have to correspond to certain leadership profiles to meet specified aspects of work objectives (Petrides, 2010). Ganji, 2011 also states that EI develops creativity in individuals, which in turn helps in the improvement of job and collective organizational performance. According to Vrab, (2007) individuals with a high level of EI relate to higher levels of transformational leadership capability, subsequently leads to higher collective organizational performance. Thus, EI is linked to various themes of work organizational performance, including work and collective organizational performance ratings, inter-personal relationships and merit salary increases due to higher levels of EI enabling people to manage to their emotions better and cope better with stress or perform under pressure (Hoffmann, 2010). Koman \& Wolff, (2008) states that Employee leaders with EI increase not just their performance but also the teams they lead. Also, Ganji, (2011) states that communication is a very important function of $\mathrm{EI}$ in the process of job and performance.

\section{EMOTIONAL INTELLIGENCE THEORIES}

Before we put forth the conceptual model we briefly review the important theories and models of EI.

\section{Goleman's Emotional Intelligence Theory}

Goleman et al., (2002), a psychologist who made Emotional Intelligence popular, suggested that EI is summarised by four elements, which are briefly explained and described below:

- Self-Awareness: Refers to the ability to know one's emotions, strengths, weaknesses, values, and goals. This ability then helps one to comprehend the impact of these emotions on others 
Table 1. Social competencies from emotional awareness

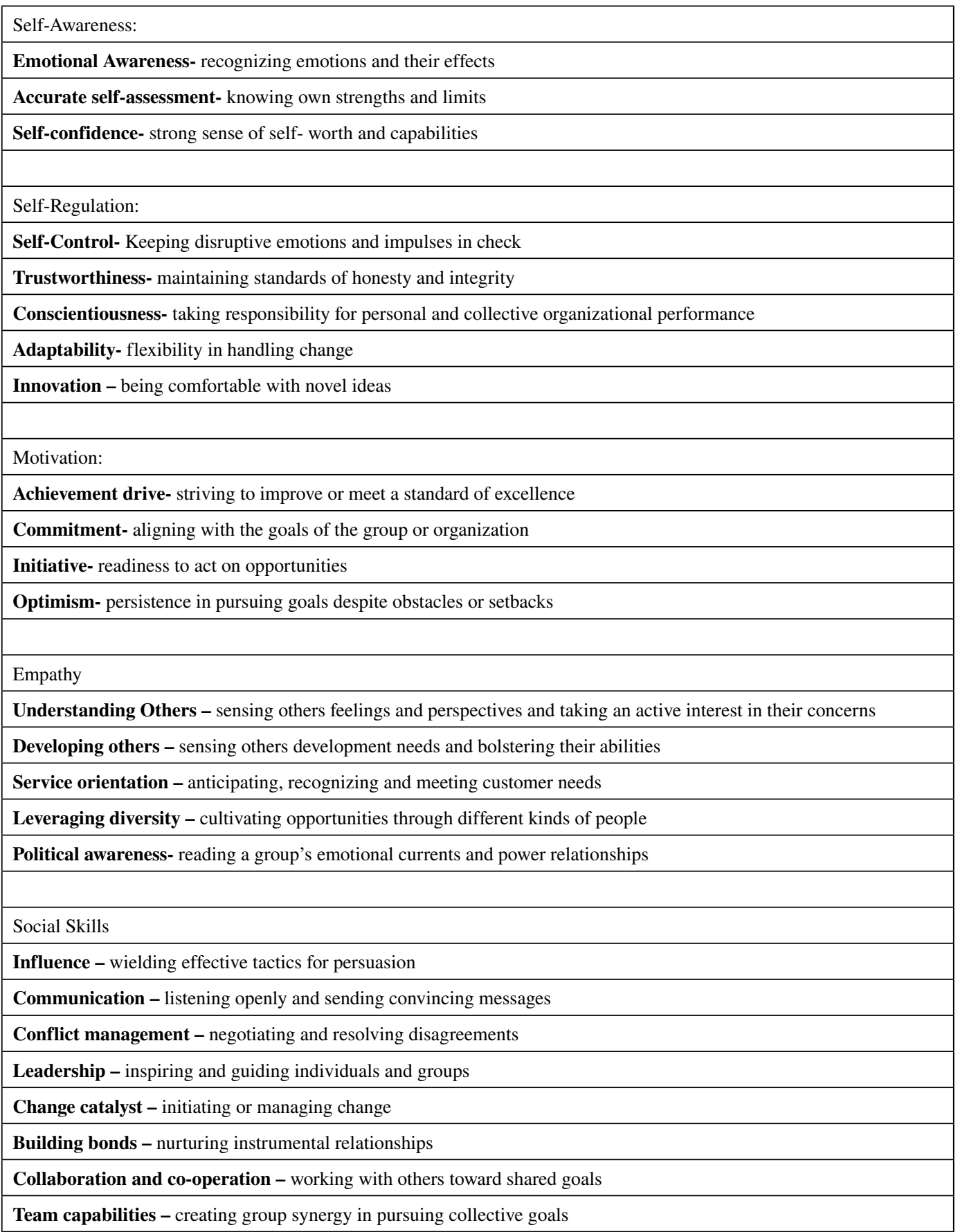

Source: Adapted from Goleman (1998)

and to use such understandings in taking positive decisions. Empathy is another aspect of the emotional competences model as it develops with self-awareness, and the more developed one is at understanding one's own emotions, the more skilled one becomes at reading the emotions 
of others. Part of EI is understanding another person's feelings and undertones through cues, tone of voice, gestures, and facial expressions (Goleman, 1995; cited in Mankowitz, 2018, p. 68).

- Self-Management: Is the skill to control or redirect one's emotions, anticipating consequences for acting on impulse and/or adapting to changing circumstances. Such a skill then helps one to act appropriately at any given point.

- Social Awareness: Is the ability to consider others' feelings, especially when making decisions and/or the urge to drive for achievement, utilizing emotional factors to achieve goals, enjoying the learning processes, and perseverance in the face of obstacles. This ability is crucial especially to those on supervisory roles since their knowledge of how their staff is feeling will help their organization immensely to enhance job satisfaction.

- Social Management: Is the proficiency in managing relationships, inspiring others, and inducing the desired responses from them. This ability is key in maintaining positivity in any organization, which is needed for job satisfaction and increased productivity.

Goleman et al., (2001) describe EI as a wide array of skills that drive leadership and emotional competence and a learned capability that results in outstanding performance at work. This ability to understand others' emotions can help employees in leadership roles to understand the degree to which subordinates' hope are important (Hoffmann, 2010).

\section{Gardner's Theory of Multiple Intelligences}

Gardner (1983) developed the theory of multiple intelligences in 1983. The type of emotional intelligence is borrowed from two of the nine ways in which human beings can be intelligent known as Gardner (1983) documented multiple intelligences and these and his team. These two bits of intelligence include our intrapersonal intelligence (how self-aware we are and how well we run the show ourselves) and our interpersonal intelligence (how aware of others we are and how well we run the show with our relationships. Below is a shortened definition of each of these theories. Intrapersonal intelligence: To understand interpersonal intelligence, one has to start with a clear understanding of what it requires to be 'intelligent'. Shankman, Allen, Haber-Curran \& Komives (2015), emphasizes that being intelligent is picking up what is prevailing within us and doing what we need to do about it. This is a very important skill since it involves understanding what happens within oneself and acting on it. This means that when people are intelligent it assists them to make sense of the things they do, the thoughts they have, the sentiments they feel, and the relationships between them all. With interpersonal intelligence, one can burn the midnight oil on how to stay in charge of oneself and one's emotions. The self-awareness on which intrapersonal intelligence is hinged assists human beings to be self-managing. This entails managing our moods, inspiring ourselves, dealing with setbacks, using our intuition, managing our energy, dealing with stress, and preventing depressions and hooking behavior. Be that as it may, interpersonal intelligence is about picking up what is going on in other people's lives and doing what is required that will assist others (Shankman, Allen, HaberCurran \& Komives, 2015). In this regard, being intelligent means tuning into other staff members, empathizing with them, communicating tacitly with them, inspiring, motivating, and appreciating the relationships with them and the relationships that exist between them.

- Self-Awareness: In modern psychology, self-awareness has become very important. Put simply, self-awareness is about being in touch with our bodily and emotional state every moment, and awareness of others is about being able to notice another's the bodily and emotional state (Diamond, 2010). Such a skill is therefore crucial in any relationship be it social or business;

- Reflective Learning: One of the essential practices of an emotionally intelligent person is drawing on the experience and thus learning from it, about oneself and others. In this regard, reflective learning permits one to convert self-awareness and keenness of others at the moment 
into self-knowledge and appreciating others, which are longer-term attributes. This is reflected in the extended version of the overall model of EI (Burnestein, 2014);

- Self-Management: Once a person is aware of who they are and who other people are, they will be able to manage themselves. Self-management and relationship management are skills that demonstrate effective leadership. One can go as far as articulating that being a good leader requires emotional intelligence and being emotionally intelligent means that one will demonstrate good leadership (Goleman, 2014);

- Relationship Management: For any relationship to flourish, they have to be managed well. Research has shown that social intelligence is the capability to comprehend others and act prudently in human relations and that it is a feature of the employee's EI. It is therefore encouraged that human beings should use humor and play to relieve stress. Humour, laughter, and play are natural remedies for stress (Low, 2013).

\section{Theories of Piaget and Vygotsky}

Concerning an adult's ability to think logically and draw valid conclusions, Piaget (1936) undertook to investigate this phenomenon. Piaget's theory rests on the fundamental notion that the child develops through stages until he or she arrives at a stage of thinking that resembles that of an adult. One of his fundamental assumptions is that early intellectual growth arises primarily out of the child's interactions with objects in the environment (Bornstein \& Lerner, 2018).

Vygotsky's (1978) socio-cultural theory of human learning describes learning as a social process and the origination of human intelligence in society or culture. Vygotsky's major theoretical framework is that social interaction plays a fundamental role in the development of cognition. To this effect, the belief is that everything is learned on two levels. This theory stipulates that within the child's cultural development every function appears first on the social level and later, on the individual level that is between people (inter psychological) and then inside the individual (intra psychological). Another aspect is that the potential for cognitive development is limited to zone of proximal development. This zone is the area of exploration for which the student is cognitively prepared but requires help and social interaction to develop fully (Briner, 1999).

\section{EMOTIONAL INTELLIGENCE MODELS}

\section{Ability Model of El}

Mayer and Salovey's ability model (1997) identifies four facets through which a person becomes emotionally intelligent. These are: perceive emotions; reasoning with emotions; emotional understanding; and emotional management. The first step - emotional perception - is an ability to be self-aware of emotions and to express them accurately. When a person is aware of the emotions he is undergoing, he moves on to the next level - reasoning with emotions, is to differentiate between the diverse emotions he is undergoing and identify. By then he becomes proficient in dealing with his emotions and thus can manage his emotions by linking to or detaching from any emotion at any given situation. This gives him complete control over his impulses and is thus able to think, analyze, and behave rationally in any situation. One will be able to identify emotions at any given moment and shift from one emotion to another. Besides, Cobb and Mayer (2000) theorized EI as well-founded in the school and organizational environments where emotions are mirrored as relationships. Cobb and Mayer (2000) also refer to this model and state that "emotional intelligence leads to good behavior."

Petrides, Sangareau, Furnham, and Frederickson (2006) criticize ability emotional intelligence in favor of trait emotional intelligence. These authors (Petrides et al., 2006) assert that the notion of trait emotional intelligence being mainly concerned with a group of emotionrelated self-perceived abilities and dispositions measured via self-reports is what distinguishes it from ability emotional intelligence. 


\section{Mixed Model of EI}

The mixed models of emotional intelligence comprise measures consisting of a combination of trait emotional intelligence and ability emotional intelligence (Austin, 2010; cited in Dhliwayo, 2018, p. 110). Therefore, the conceptualizations of emotional intelligence by Bar-On (1997; cited in Dhliwayo, 2018, p. 110) and Goleman (2001; cited in Dhliwayo, 2018, p. 110) fit well within the domain of mixed models of emotional intelligence. Goleman and Bar-On "mixed model" (1999) describes a range of abilities which are broken down into skill sets and together give a picture of a person's emotional intelligence level this view encompasses abilities:

- Self-Awareness: To have an understanding of how a person feels and be able to assess one's emotional state. It drives decision-making, gives a strong sense of self-confidence, and the understanding of a person's skills. There are three components such as:

- Emotional Self-Awareness: Assess one's emotional state;

- Accurate Self-Assessment: Understanding one's strength and weaknesses;

- Self-Confidence: Is the ability to be secured and confident in whatever situation one may find yourself;

- Self-Management: Builds on the understanding that a person attained self-awareness and involves controlling his emotions so that emotions do not control him. In other words, control our own emotions so that they do not hinder but assist; order to improve and succeed. It is the ability of how a person regulates to maintain his balance when he faces any problems. In includes ability like Self-Control, Trustworthiness, Conscientiousness, Adaptability, Achievement Orientation, and Initiative;

- Social Awareness: Involves increasing a person's awareness to embrace the emotion of those people around him. Identifying what others are feeling; being able to understand situations from others' viewpoints; nurturing relationships with a diverse group of people. It includes Empathy, Organizational Awareness, and Service Orientation;

- Social Skills: Manage emotions for relationships with other people, understand and read the complexities of social relations interact in social situations. EI has more supremacy than IQ twice (Goleman, 1998) and it can be considered as an indicator for future success and accomplishments (Goleman 1995 \& 1998).

Regarding the relationship with job performance, mixed models may have a better relationship with job performance than trait emotional intelligence. This is because measures of mixed emotional intelligence include components of personality, personal preferences, and attitudes, making it natural for them to capture a broad range of attributes, leading to better explanation of job performance Cherniss (2010; cited in Dhliwayo, 2018, p. 111). Mixed models of emotional intelligence have also been scrutinized in terms of their relationship with other models of emotional intelligence and personality. Further, mixed models of EI have a better relationship with personality measures than with ability models, mainly because they seem to overlap with personality in terms of the measurement methods and the items contained (Dhliwayo, 2018). As a result, they show a higher correlation with personality than with ability measures.

\section{Trait Model of El}

According to Mankowitz (2018), conceptual differences between EI and Trait EI are demarcated as a collection of self-perceptions located at the lower levels of personality hierarchy. EI ability is the ability to perceive and express emotion, assimilate emotion in thought, understand and reason with emotion, and regulate emotion in the self and others (Mayer \& Salovey, 1997, Mankowitz, 2018). Thus, EI has four factors. These factors include perception of emotion, managing own emotions, managing others' emotions, and utilization of emotion. Evidence also suggests that trait emotional 
intelligence is rich from both explanatory and predictive viewpoints. This is also supported by the study conducted by Hui-Hua and Schutte (2015; cited in Dhliwayo (2018, p. 103). Trait emotional intelligence is useful because it combines within one framework the main individual differences in the levels of affect which have been hitherto scattered across the basic personality dimensions (Dhliwayo, 2018). Petrides (2011) and colleagues published this model in 2009 the most prominent view in the scientific literature is that the Trait model view EI, as a collection of personality traits claiming they are merely emotional self-perceptions and does not context specific. This model is different from the Ability and Mixed model which states that EI is a mind-based ability (Furnham, 2012).

\section{CONCEPTUAL MODEL}

This study is not in isolation. It builds on the cascading model described by Joseph and Newman (2010) and supported by the findings (Gunkel, Schlaegel, \& Engle, 2014) by exploring the influence of cultural dimensions on a cascading model of EI towards organizational performance as seen on Figure 3.

The model in figure 3 shows a conceptual model of how EI is connected to organizational performance. To make this study unique, the model, as depicted in figure 3 , will be used from the qualitative approach perspective. As seen in figure 3, the progressive (cascading) pattern among ability-based EI facets, in which emotion perceptions must causally precede emotion understanding, which in turn precedes conscious emotion regulation and job collective organizational performance (Joseph and Newman, 2010).

The model of EI is empirically confirmed through metadata analytic, although relationships between ability-based EI and job and organizational performance are shown to be inconsistent (Joseph and Newman, 2010), such as EI positively predicts collective organizational performance for high emotional labor jobs and negatively predicts collective organizational performance for low emotional labor jobs). Further, Table 2 summarises the integration of cognitive and EI models.

\section{Figure 3. El cascading model}

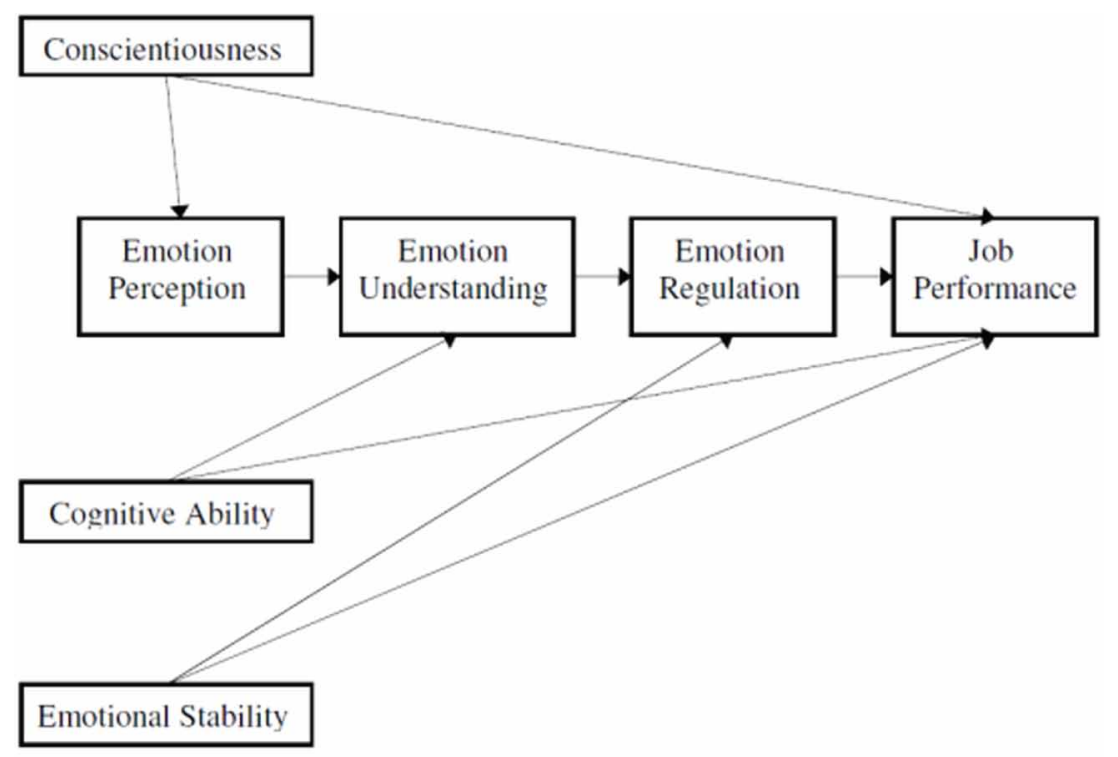

Source: Adapted from Joseph and Newman (1997) 
Table 2. Cognitive and El models integration

\begin{tabular}{|c|c|c|c|c|}
\hline \multirow[b]{2}{*}{ Dimensions } & \multicolumn{4}{|c|}{ Cognitive and EI Models } \\
\hline & $\begin{array}{l}\text { General Mental } \\
\text { Ability (Spearman, } \\
\text { 1904, 1927a) }\end{array}$ & $\begin{array}{c}\text { Trait Model } \\
\text { (Schutte et al., 1998; } \\
\text { Petrides \& Furnham } \\
\text { (2003) }\end{array}$ & $\begin{array}{c}\text { Ability Model } \\
\text { (Mayer \& Salovey, } \\
\text { 1997; Wong \& Law, } \\
\text { 2004). }\end{array}$ & $\begin{array}{c}\text { Mixed Model } \\
\text { (Bar-On, 1998; } \\
\text { Boyatzis \& Goleman, } \\
\text { 2000) }\end{array}$ \\
\hline Construct definition & $\begin{array}{l}\text { Cognitive intelligence } \\
\text { is unitary and predicts } \\
\text { organizational } \\
\text { performance across } \\
\text { most occupations. }\end{array}$ & $\begin{array}{l}\text { A constellation of } \\
\text { emotion-related } \\
\text { self-perceptions and } \\
\text { dispositions assessed } \\
\text { through self-reports } \\
\text { and located at the lower } \\
\text { level of the personality } \\
\text { hierarchy. }\end{array}$ & $\begin{array}{l}\text { Well-defined, } \\
\text { conceptually related } \\
\text { set of cognitive } \\
\text { abilities necessary for } \\
\text { processing emotional } \\
\text { information and } \\
\text { adaptively regulating } \\
\text { emotions. }\end{array}$ & $\begin{array}{l}\text { An array of } \\
\text { non-cognitive } \\
\text { capabilities and } \\
\text { skills that influence } \\
\text { the ability to cope } \\
\text { with environmental } \\
\text { demands and } \\
\text { pressures. }\end{array}$ \\
\hline Components & $\begin{array}{l}\text { Cognitive ability } \\
\text { is subsumed under } \\
\text { one general factor of } \\
\text { intelligence }(\mathrm{g}) \text { which } \\
\text { defines intelligence as } \\
\text { unitary. }\end{array}$ & $\begin{array}{l}\text { Components vary } \\
\text { depending on the test } \\
\text { developer but must } \\
\text { demonstrate good } \\
\text { construct and predictive } \\
\text { validity. }\end{array}$ & $\begin{array}{l}\text { Components vary } \\
\text { depending on the test } \\
\text { developer but must } \\
\text { demonstrate good } \\
\text { construct and predictive } \\
\text { validity }\end{array}$ & $\begin{array}{l}\text { Components vary } \\
\text { depending on the } \\
\text { test developer but } \\
\text { must demonstrate } \\
\text { good construct and } \\
\text { predictive validity. }\end{array}$ \\
\hline Link with personality & $\begin{array}{l}\text { Apart from a high } \\
\text { relationship with } \\
\text { conscientiousness and } \\
\text { intuition, a relationship } \\
\text { with personality is low. }\end{array}$ & $\begin{array}{l}\text { High positive } \\
\text { Relationship with } \\
\text { personality. }\end{array}$ & $\begin{array}{l}\text { Low relationship with } \\
\text { personality. }\end{array}$ & $\begin{array}{l}\text { Moderate relationship } \\
\text { with personality. }\end{array}$ \\
\hline $\begin{array}{l}\text { Link with job } \\
\text { organizational performance }\end{array}$ & $\begin{array}{l}\text { Very high relationship } \\
\text { with job organizational } \\
\text { performance across } \\
\text { most if not all } \\
\text { occupations. }\end{array}$ & $\begin{array}{l}\text { Some relationship } \\
\text { with job organizational } \\
\text { performance but predicts } \\
\text { job performance better } \\
\text { for emotional labor } \\
\text { jobs. High incremental } \\
\text { validity beyond } \\
\text { cognitive intelligence. }\end{array}$ & $\begin{array}{l}\text { High relationship with } \\
\text { job organizational } \\
\text { performance for most } \\
\text { occupations. Little } \\
\text { incremental validity } \\
\text { beyond cognitive } \\
\text { intelligence. }\end{array}$ & $\begin{array}{l}\text { Moderate } \\
\text { relationship with } \\
\text { job organizational } \\
\text { performance. } \\
\text { Predicts job } \\
\text { organizational } \\
\text { performance better for } \\
\text { high emotional labor } \\
\text { jobs. }\end{array}$ \\
\hline $\begin{array}{l}\text { Usefulness/application to } \\
\text { personnel selection }\end{array}$ & $\begin{array}{l}\text { Best single predictor } \\
\text { of job organizational } \\
\text { performance across } \\
\text { occupations. }\end{array}$ & $\begin{array}{l}\text { Low to moderate } \\
\text { relationship with } \\
\text { job organizational } \\
\text { performance but } \\
\text { predicts job collective } \\
\text { organizational } \\
\text { performance better in } \\
\text { emotional labor jobs. }\end{array}$ & $\begin{array}{l}\text { High relationship with } \\
\text { job organizational } \\
\text { performance for most } \\
\text { jobs, but redundant } \\
\text { with cognitive } \\
\text { intelligence. }\end{array}$ & $\begin{array}{l}\text { Moderate to a good } \\
\text { relationship with } \\
\text { job organizational } \\
\text { performance } \\
\text { but predicts job } \\
\text { organizational } \\
\text { performance better in } \\
\text { emotional labor jobs. }\end{array}$ \\
\hline
\end{tabular}

Source: Adapted from Dhliwayo, (2018)

\section{EMOTIONAL INTELLIGENCE FOR ORGANIZATIONAL PERFORMANCE: FINDINGS AND DISCUSSION}

\section{Demographic Analysis}

Of the 40 copies of questionnaires distributed to the employees at NHE 40 were returned, yielding a response rate of $100 \%$. Thus, the response rate can be ranked as very excellent, due to the various measures taken and the fact that the researcher is working and known by the employees. The respondents were asked to specify their gender (question 1). There were $20(50 \%)$ male and $20(50 \%)$ female respondents. The age group that participated in the questionnaire were mainly from the age of 41 to 20 . This age group was followed by $30 \%$ of representatives from the age group of 31 to 40. The participants in the questionnaire were mainly dominated by general workers and executive representation was only $15 \%$ of the participants in the same questionnaire. 


\section{Emotional Self-Awareness}

The figures, 4, 5, 6, and 7 represent the emotional self-awareness of the participants. For the emotions the participants feel and why (figure 4), the results show an average dominance. Figure 5 shows good and very good dominant results for "the links between my feelings and what I think, do, and say." The understanding of how the feelings affect Organizational Performance, in figure 6 is dominated by 'good' by the participants. Whereas, the guiding awareness of my values and goals by the participants is dominated by average, see figure 7 .

Figure 4. Always know which emotions I am feeling and why

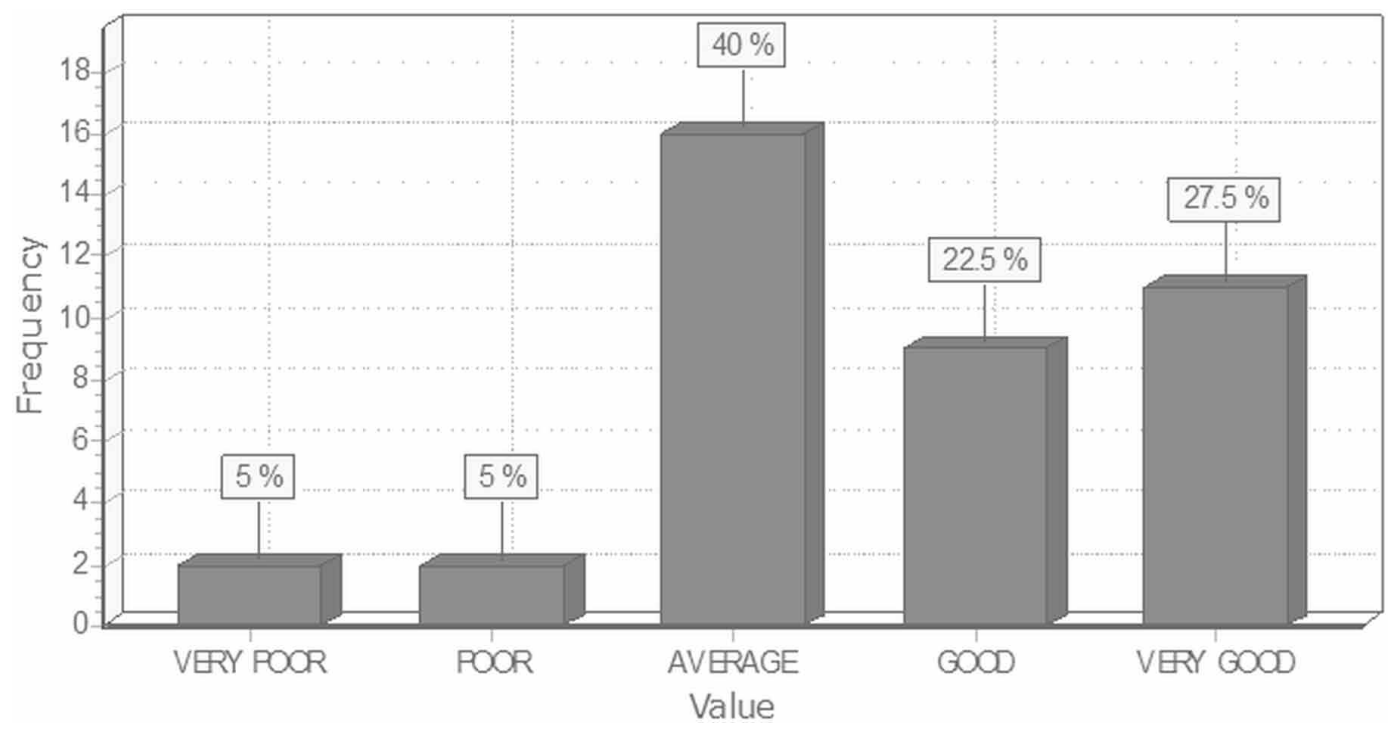

Figure 5. Realize the links between my feelings and what I think, do, and say

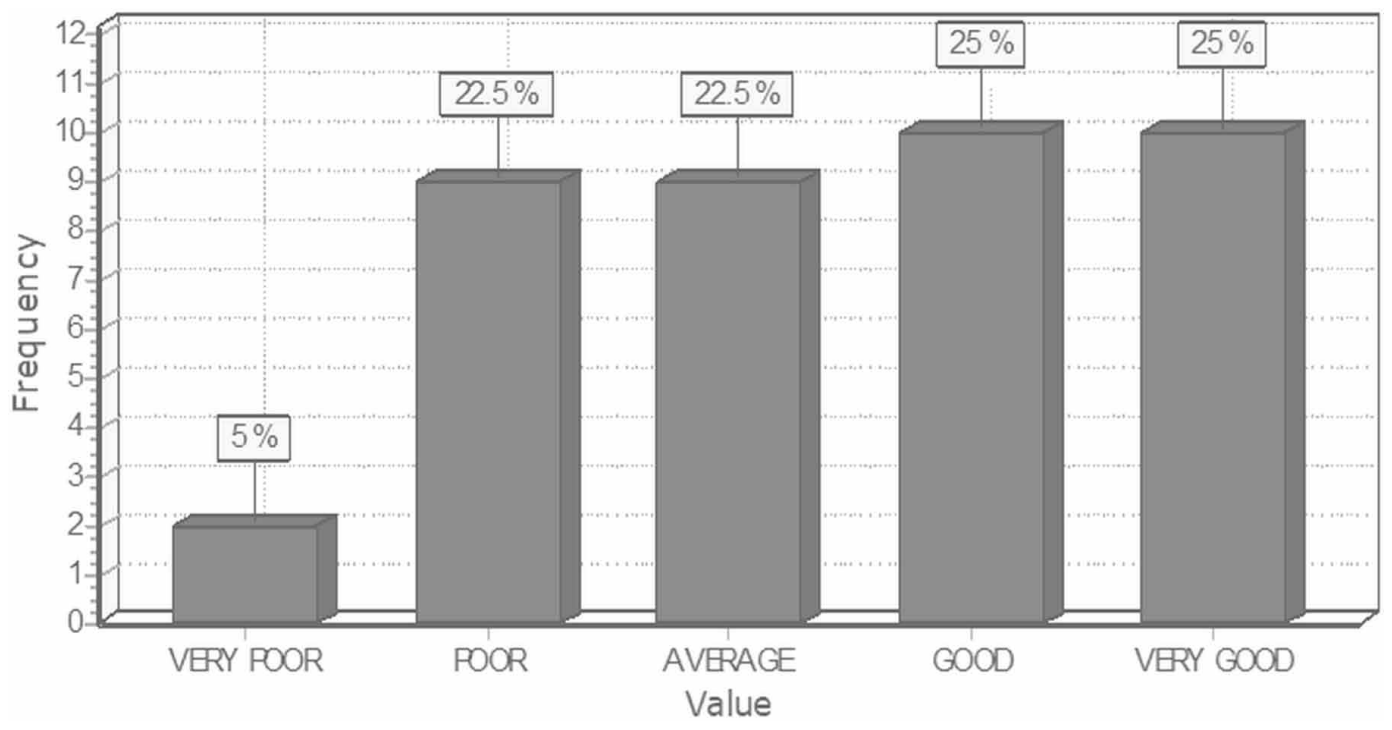


Figure 6. Recognize how my feelings affect my job and organizational performance

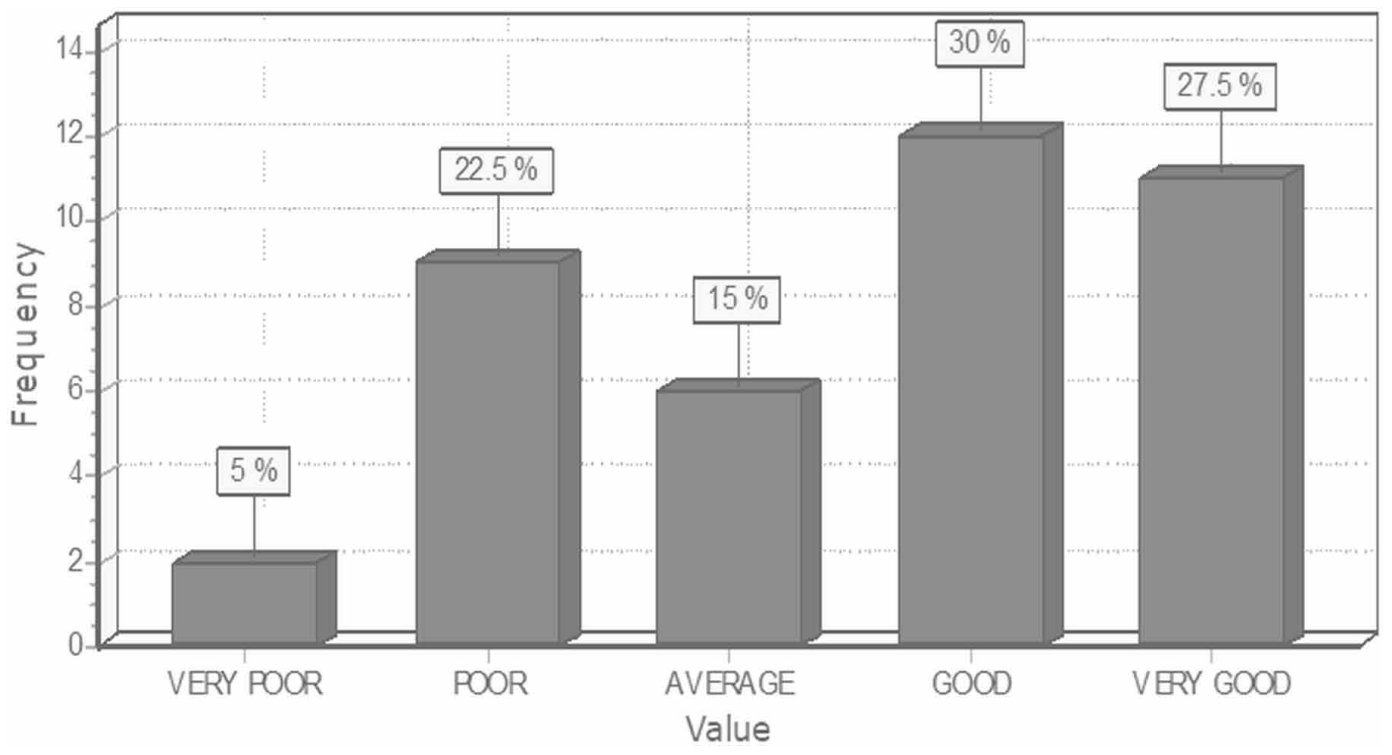

Figure 7. Have guiding awareness of my values and goals

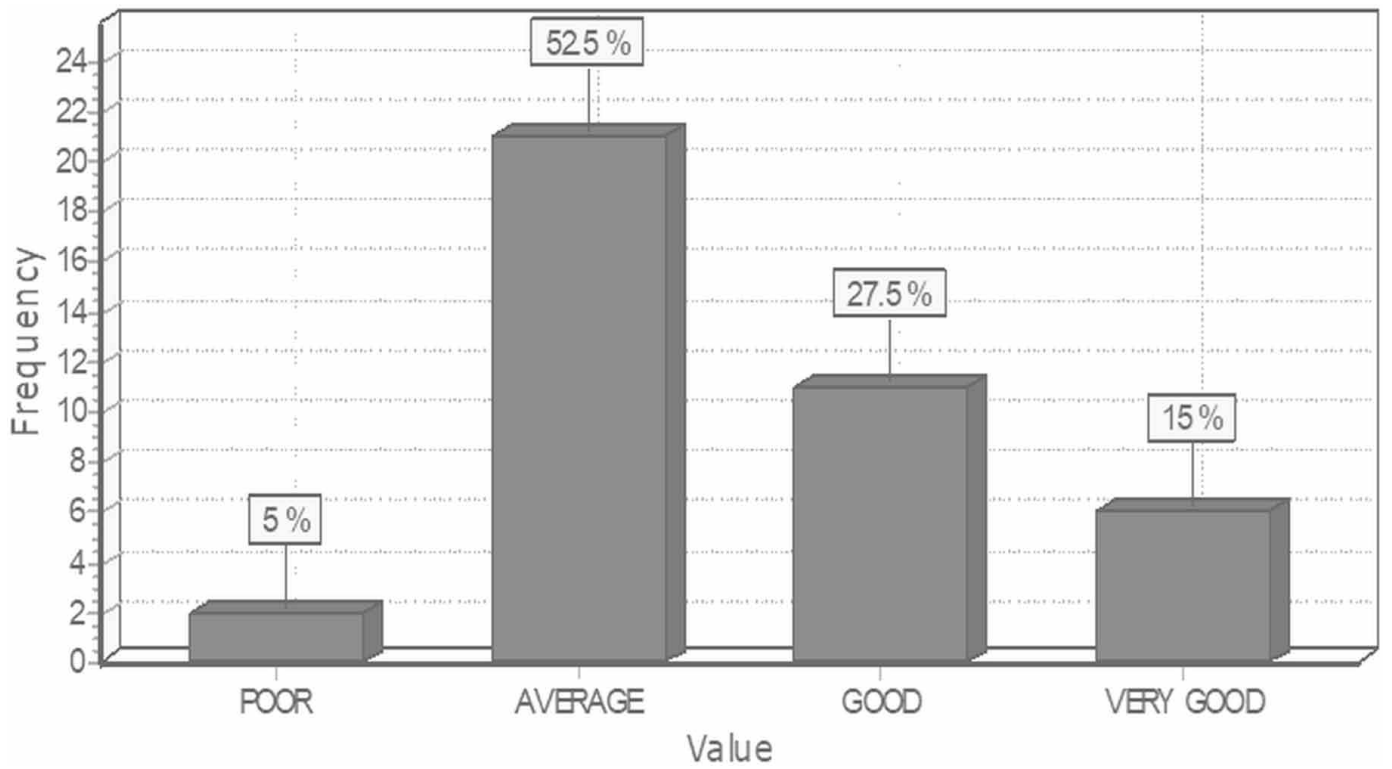

\section{Self-Assessment}

Figures 8, 9, 10, and 11 show that there is a good EI with regards to self-assessment. Despite figure 8 showing average results, this is followed by a slight difference of just over $2 \%$ to that of the good rank.

\section{Self-Control}

The self-control aspect of the participant, concerning EI, are given in Table 3. 
Figure 8. Aware of my strengths and weakness

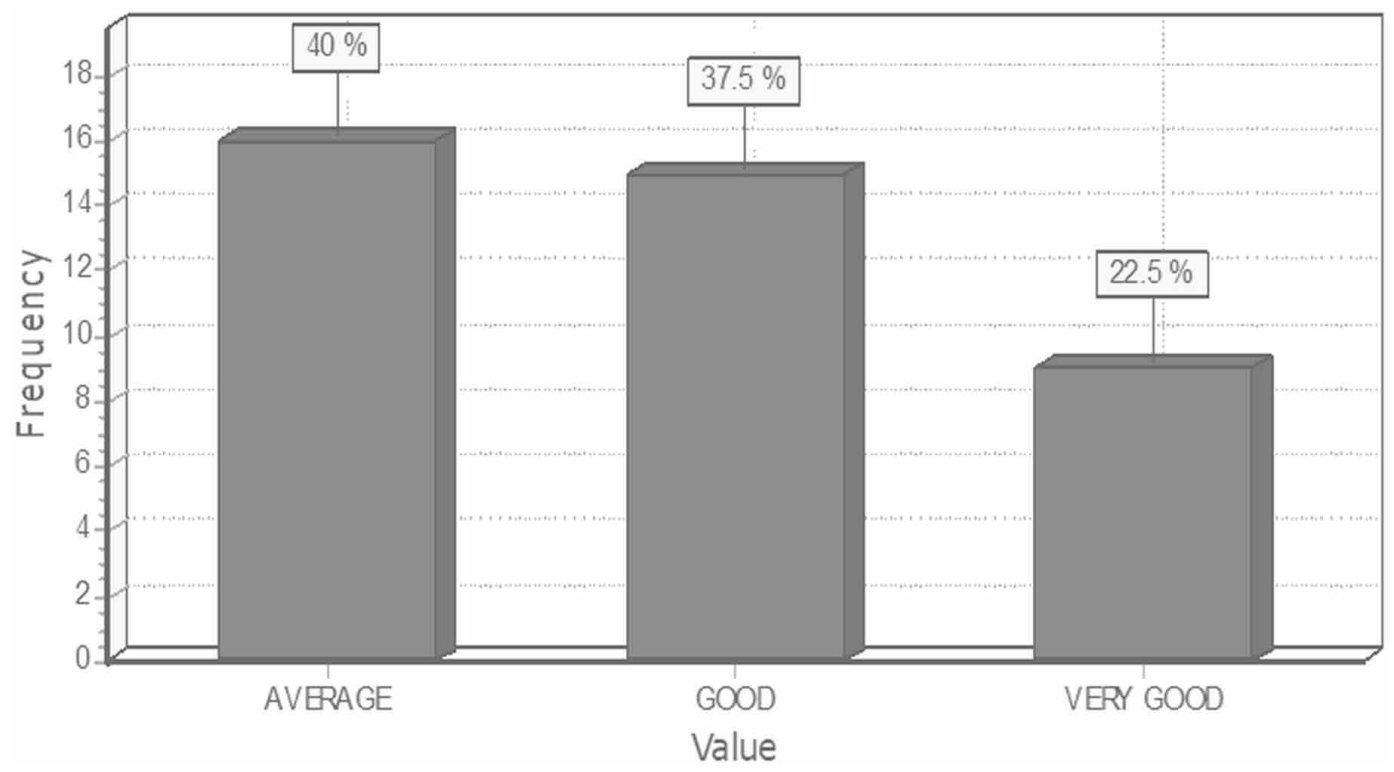

Figure 9. Reflective and try to learn from experience

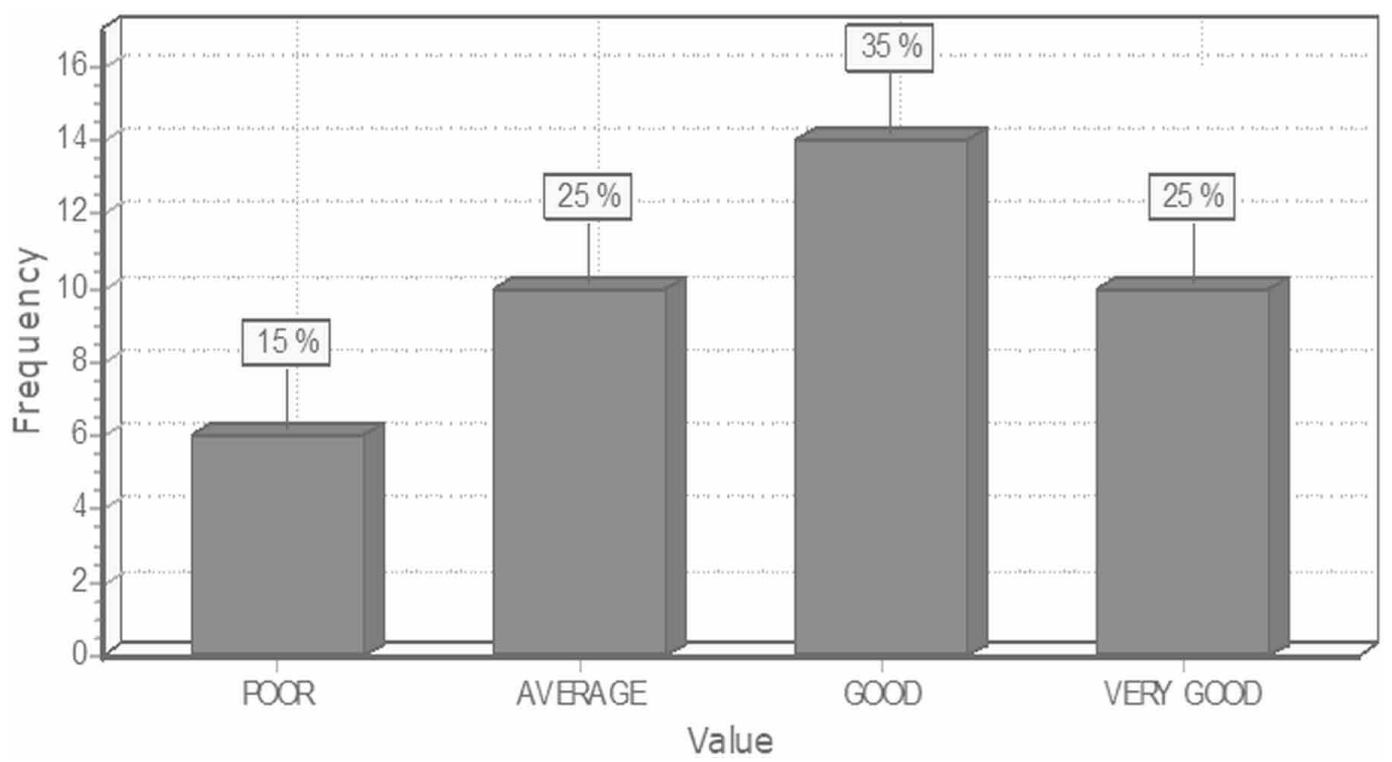

\section{Responsibility}

Despite figure 12 indicating that there is an over $30 \%$ of participants maintaining standards of honesty and integrity, figure 13 has an average response rate of participants indicating to provide original solutions to the problem. 
Figure 10. Open to feedback, new perspectives, continuous learning and self-development

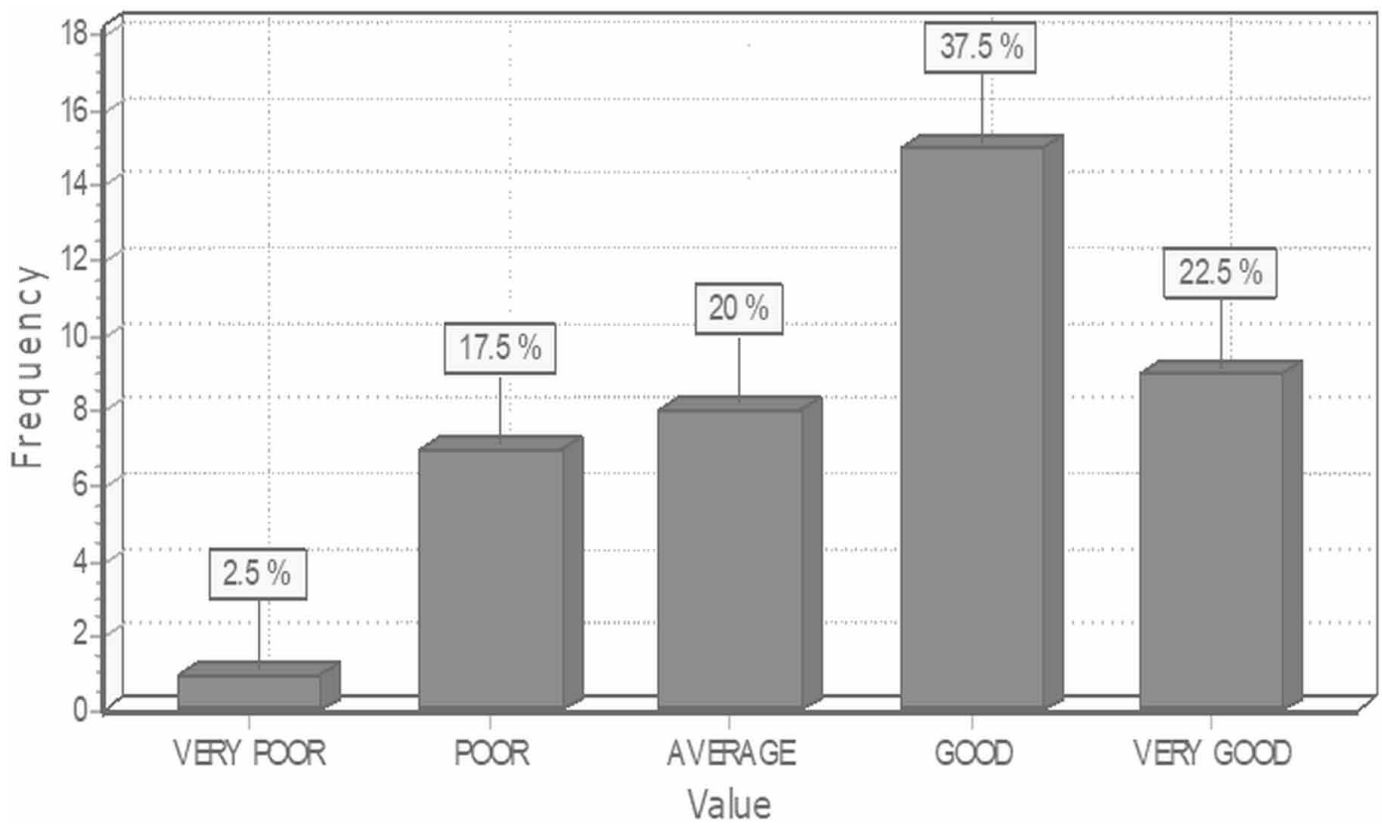

Figure 11. Be able to show a sense of humor and perspective about me

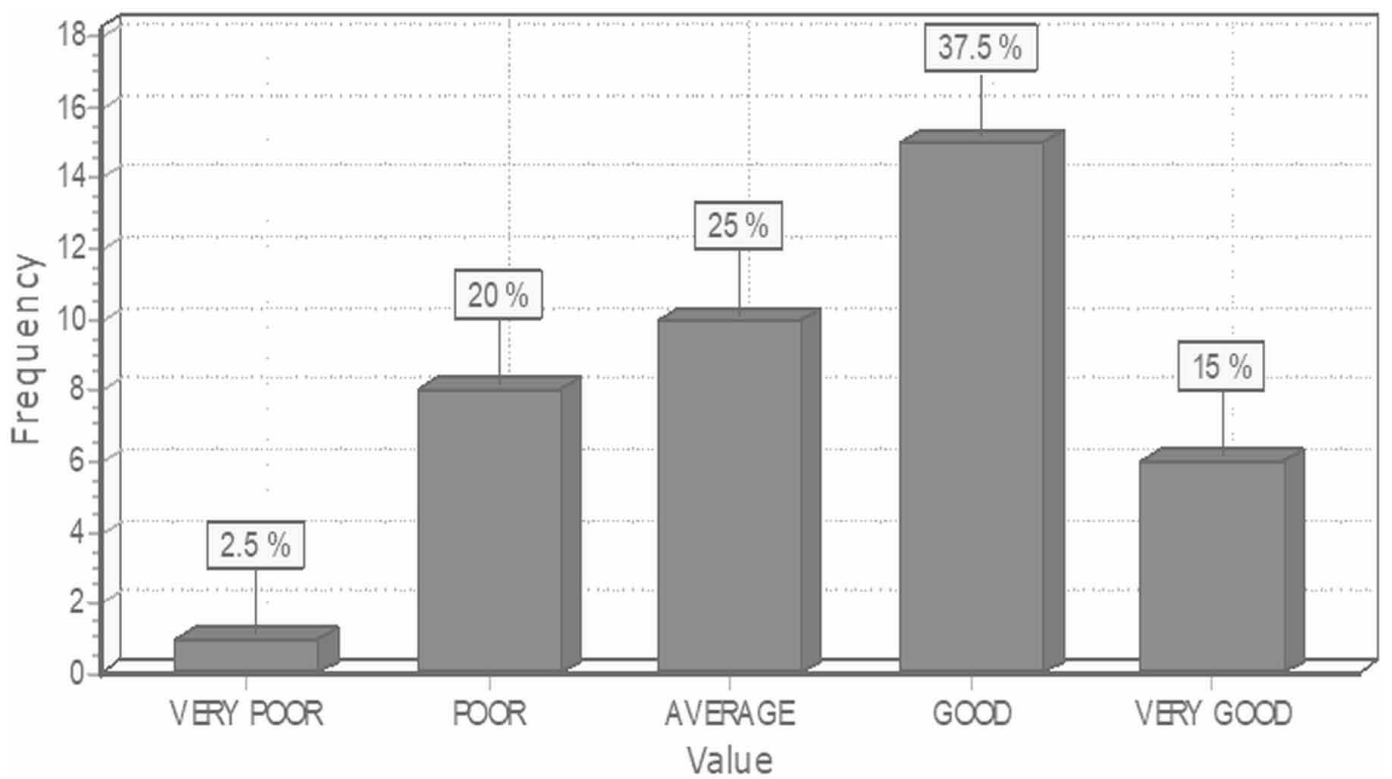


Table 3. Self-control concerning El

\begin{tabular}{|l|l|l|l|l|l|}
\hline \multirow{2}{*}{ Criteria } & \multicolumn{5}{c|}{ Percent Value of Response } \\
\cline { 2 - 7 } & \multicolumn{1}{c|}{ Very Poor } & \multicolumn{1}{c|}{ Poor } & \multicolumn{1}{c|}{ Average } & \multicolumn{1}{c|}{ Good } & Very Good \\
\hline Work under pressure & 2.5 & 17.5 & 20 & 32.5 & 27.5 \\
\hline Remain undisturbed during the critical & 2.5 & 37.5 & 20 & 25 & 15 \\
\hline Think clearly and stay focused under pressure & 0.0 & 25 & 20 & 40 & 15 \\
\hline $\begin{array}{l}\text { Appeal to the core values of the group to clarify } \\
\text { the alternatives and make the right decisions }\end{array}$ & 00 & 17.5 & 37.5 & 30 & 15 \\
\hline
\end{tabular}

Figure 12. Maintaining standards of honesty and integrity

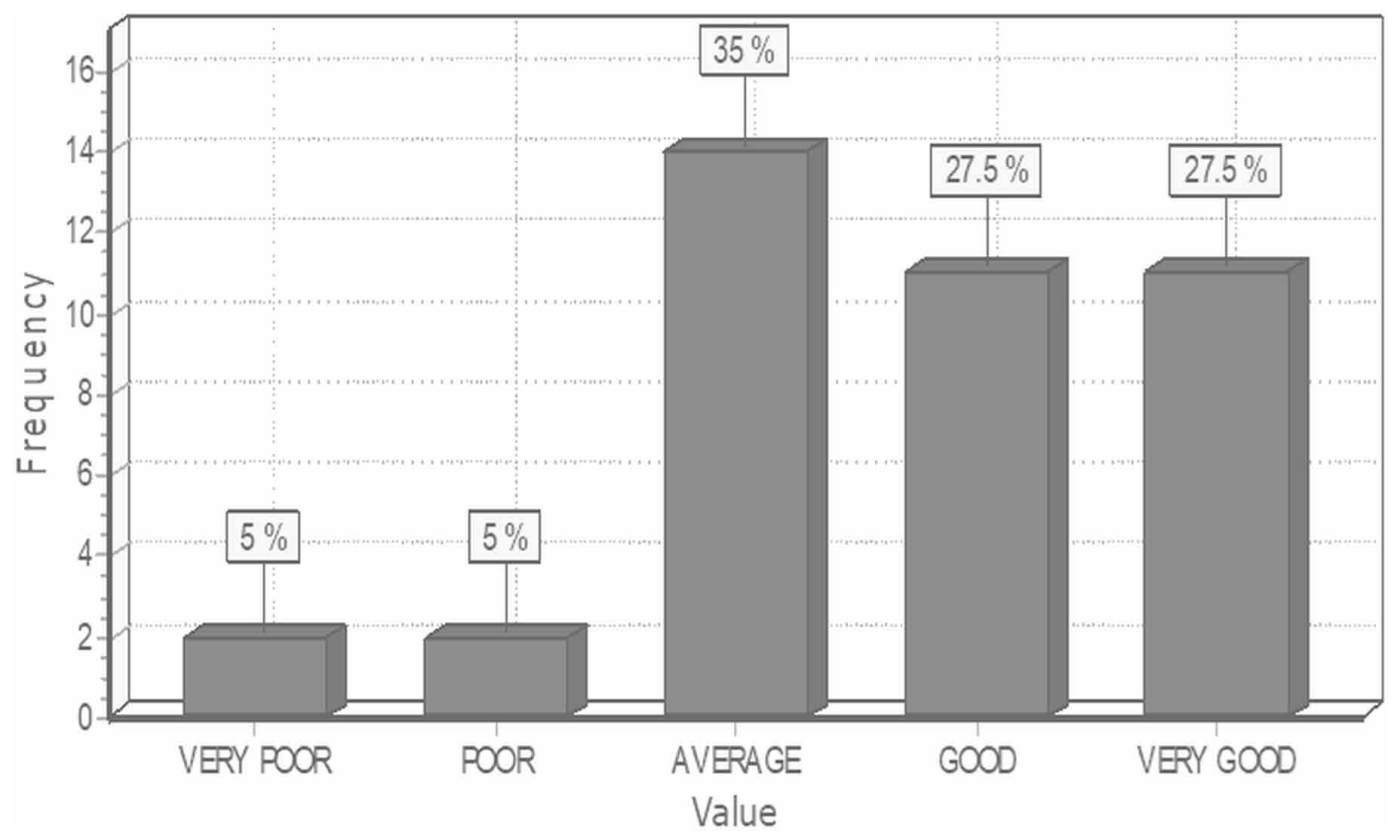

\section{Conscientious}

The conscientious aspect of the participant, concerning EI, are given in Table 4.

\section{Adaptability}

Concerning adaptability, the participants indicated that there is poor and uneven handling of multiple demands, shifting priorities, and rapid change (see figure 14).

\section{Innovativeness}

Innovativeness was also measured by the participants. Table 5 gives the measure of innovativeness.

\section{Achievement Drive}

The achievement drive of employees was also measured. Table 6 gives the achievement drive. 
Figure 13. Provide original solutions to problems

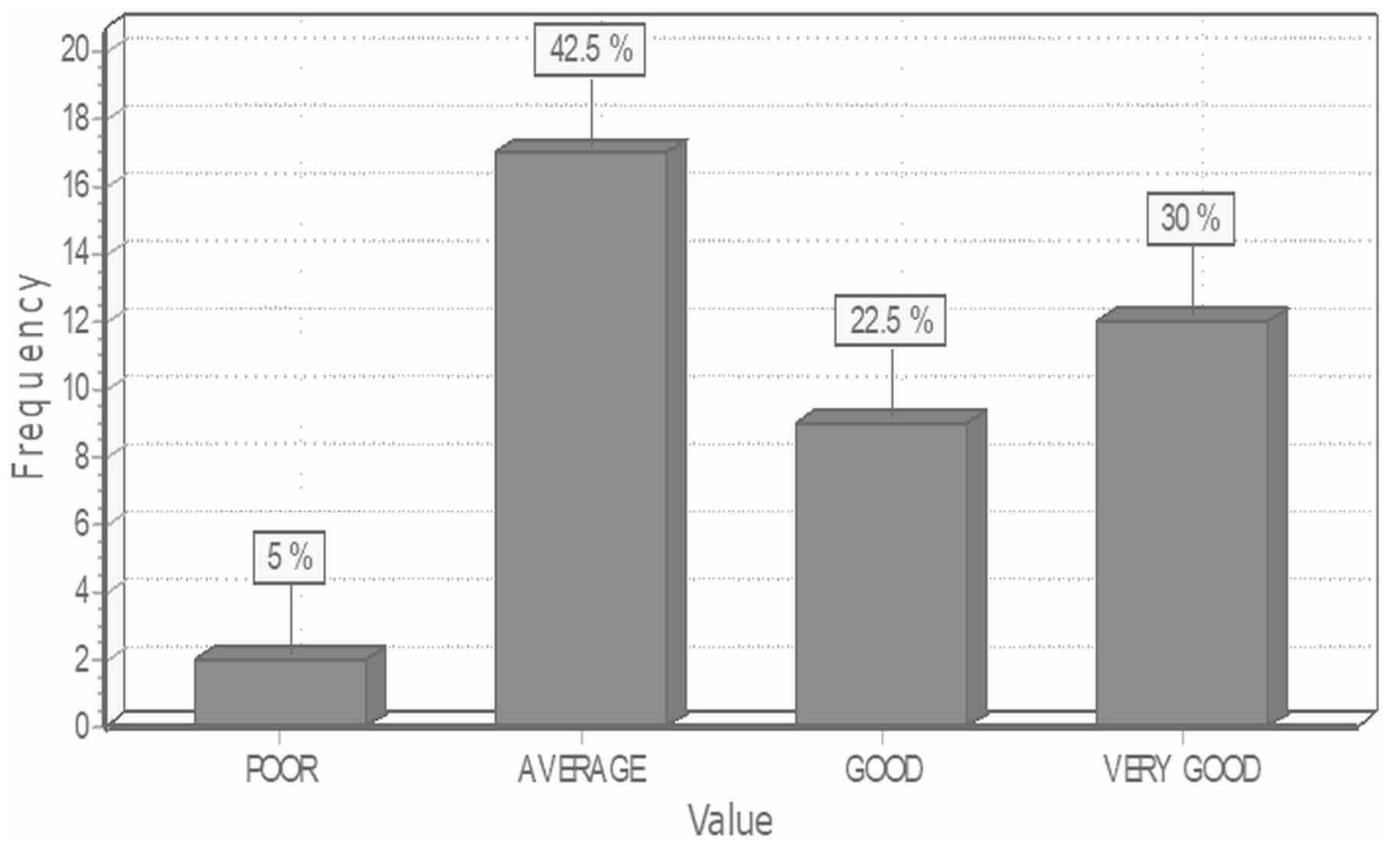

Table 4. Conscientious aspect concerning El

\begin{tabular}{|l|l|l|l|l|l|}
\hline \multirow{2}{*}{ Criteria } & \multicolumn{5}{c|}{ Percent Value of Response } \\
\cline { 2 - 6 } & \multicolumn{1}{|c|}{ Very Poor } & \multicolumn{1}{c|}{ Poor } & \multicolumn{1}{c|}{ Average } & \multicolumn{1}{c|}{ Good } & Very Good \\
\hline Meet commitments and keep promises & 00 & 10 & 35 & 32.5 & 22.5 \\
\hline $\begin{array}{l}\text { Hold myself accountable for meeting my } \\
\text { objectives }\end{array}$ & 2.5 & 7.5 & 36 & 25 & 30 \\
\hline Organized and careful in my work & 2.5 & 10 & 42.5 & 20 & 25 \\
\hline
\end{tabular}

\section{Initiative}

Figures 15, shows the initiative aspect of the employees. Figure 15 indicates that a good number of employees (45\%) are effective, capable of taking on challenges, and master new tasks.

\section{Optimism}

Optimism awareness responses from participants' results are ranging from average to good. Figure 16 indicates that the participants help out based on understanding other people's needs and feelings.

\section{Empathy}

Table 7 shows the empathy that is sensitive and understanding others' perspectives.

\section{Service Orientation}

Service orientation awareness is well understood by the employees. The participants indicated that there is a good understanding of customer's needs and matching them to services or products (figure 17). 
Figure 14. Handling of multiple demands, shifting priorities, and rapid change

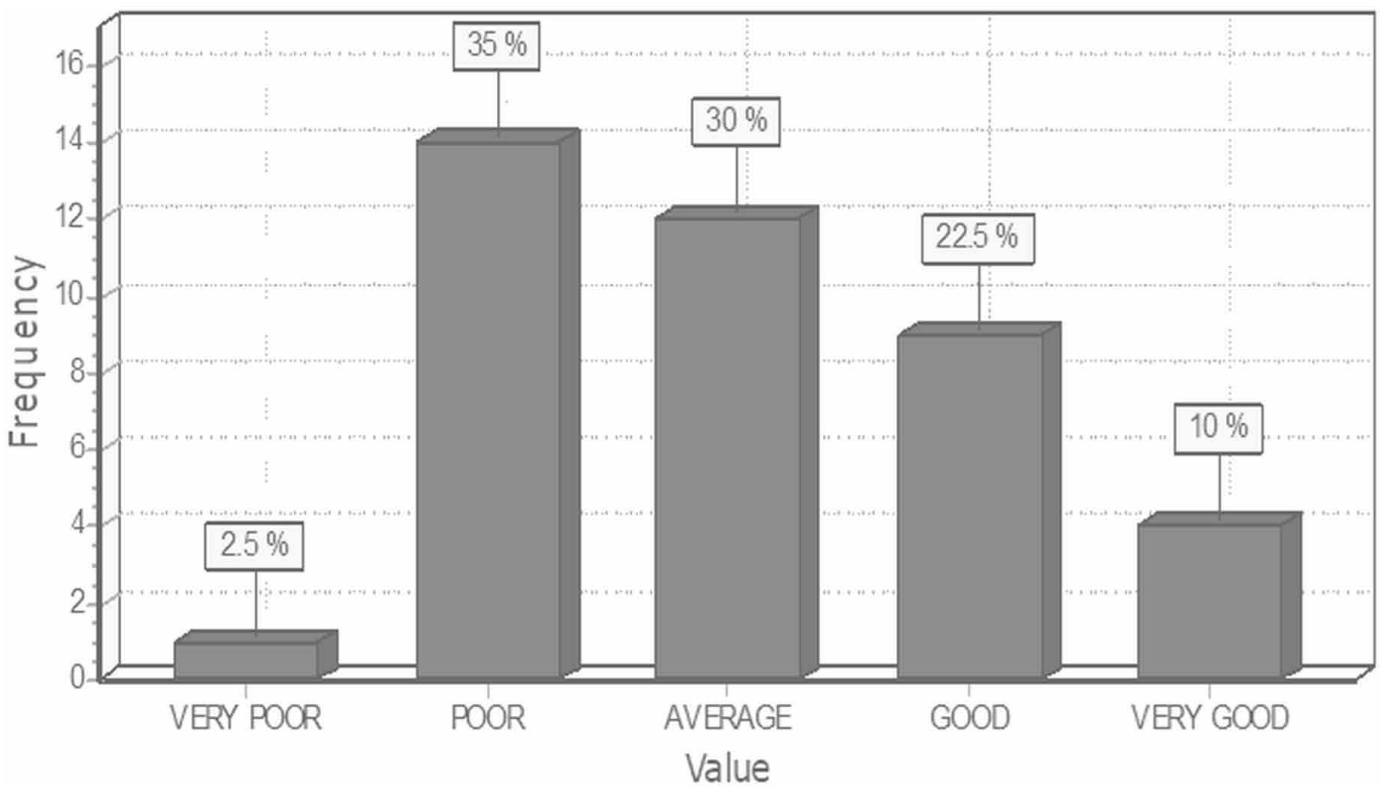

Table 5. Innovativeness

\begin{tabular}{|l|l|l|l|l|l|}
\hline \multirow{2}{*}{ Criteria } & \multicolumn{5}{c|}{ Percent Value of Response } \\
\cline { 2 - 7 } & Very Poor & \multicolumn{1}{c|}{ Poor } & \multicolumn{1}{c|}{ Average } & \multicolumn{1}{c|}{ Good } & Very Good \\
\hline Seek new ideas from varied sources & 2.5 & 7.5 & 35 & 32.5 & 12.5 \\
\hline Entertain original solutions to problems & 2.5 & 25 & 32.5 & 32.5 & 7.5 \\
\hline Generate new ideas & 10 & 27.5 & 12.5 & 37.5 & 12.5 \\
\hline Fresh perspectives and risks in thinking & 00 & 25 & 32.5 & 30 & 12.5 \\
\hline
\end{tabular}

Table 6. Achievement drive

\begin{tabular}{|l|l|l|l|l|l|}
\hline \multirow{2}{*}{ Criteria } & \multicolumn{5}{c|}{ Percent Value of Response } \\
\cline { 2 - 6 } & \multicolumn{1}{|c|}{ Very Poor } & \multicolumn{1}{c|}{ Poor } & \multicolumn{1}{c|}{ Average } & \multicolumn{1}{c|}{ Good } & Very Good \\
\hline $\begin{array}{l}\text { Results-oriented and high drive to meet } \\
\text { objectives and standards }\end{array}$ & 00 & 15 & 35 & 25 & 25 \\
\hline Set challenging goals and take calculated risks & 7.5 & 7.5 & 35 & 27.5 & 22.5 \\
\hline $\begin{array}{l}\text { Continuously learn to improve my job and } \\
\text { organizational performance }\end{array}$ & 17.5 & 12.5 & 10 & 32.5 & 27.5 \\
\hline $\begin{array}{l}\text { Pursue information to reduce uncertainty and } \\
\text { find ways of doing better }\end{array}$ & 7.5 & 22.5 & 20 & 27.5 & 22.5 \\
\hline
\end{tabular}


Figure 15. Effective, capable of taking on challenges and master new tasks

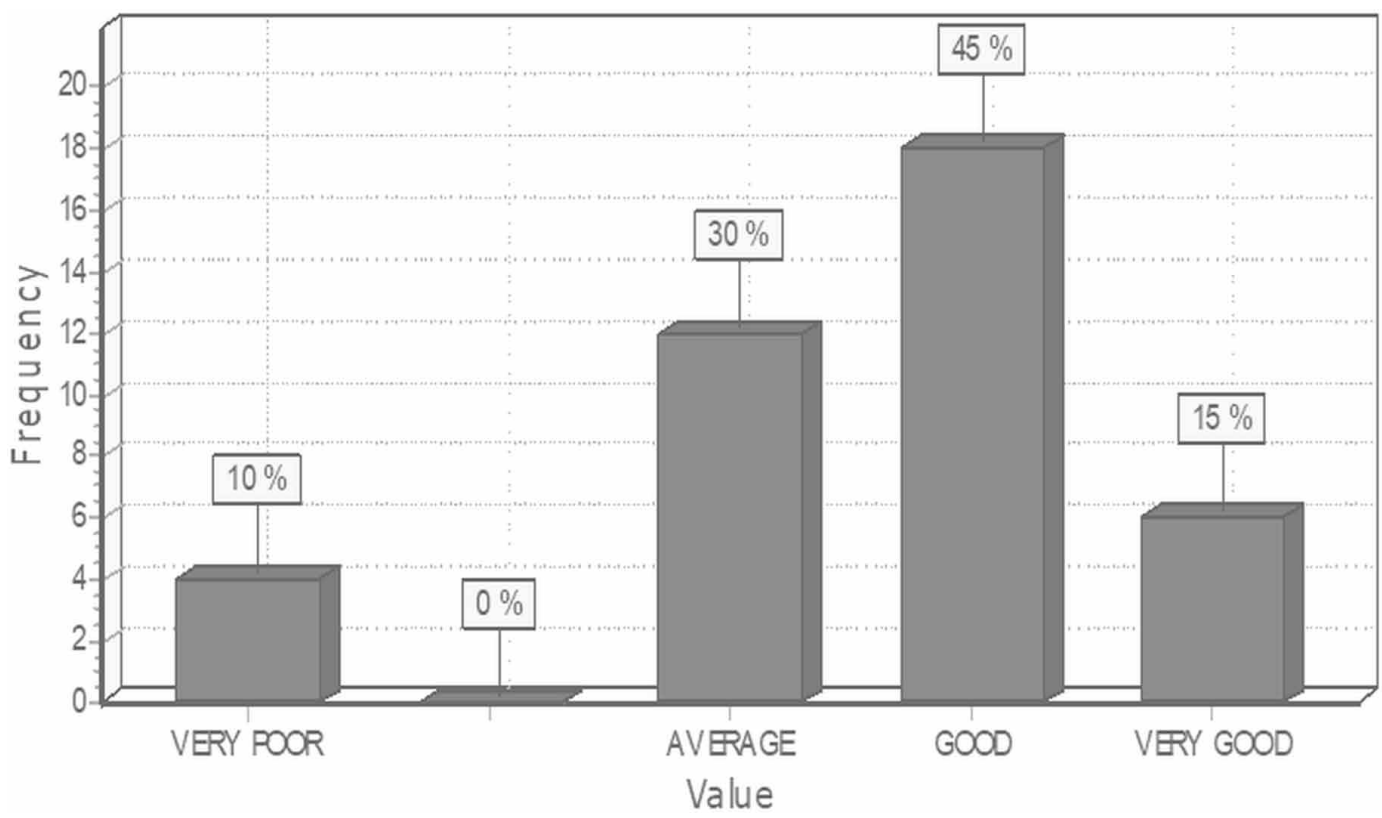

Figure 16. Help out based on understanding other people's needs and feelings

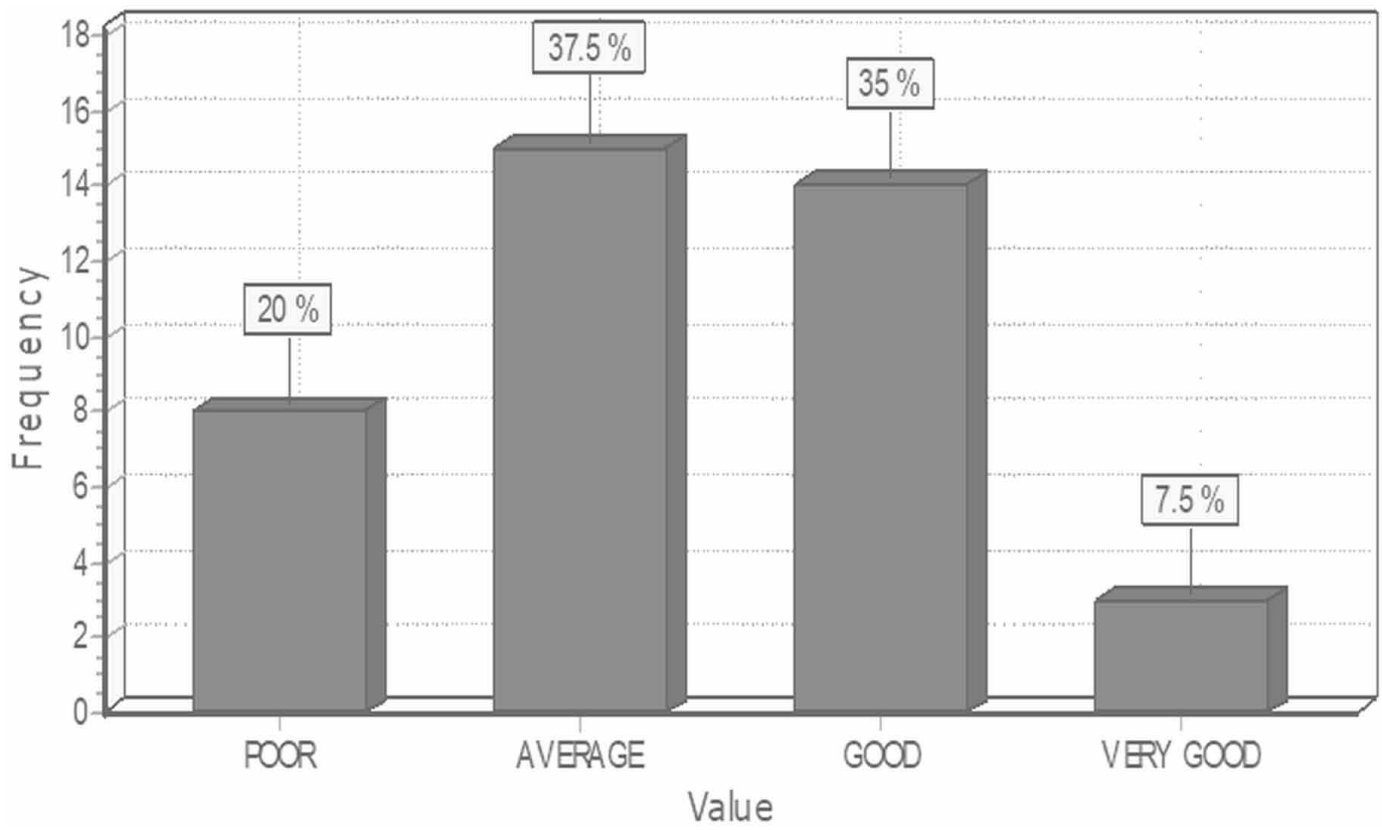


Table 7. Empathy

\begin{tabular}{|l|l|l|l|l|l|}
\hline \multirow{2}{*}{ Criteria } & \multicolumn{5}{c|}{ Percent Value of Response } \\
\cline { 2 - 6 } & \multicolumn{1}{|c|}{ Very Poor } & \multicolumn{1}{c|}{ Poor } & \multicolumn{1}{c|}{ Average } & \multicolumn{1}{c|}{ Good } & Very Good \\
\hline $\begin{array}{l}\text { Show sensitivity and understand others } \\
\text { perspective }\end{array}$ & 5 & 20 & 30 & 27.5 & 17.5 \\
\hline $\begin{array}{l}\text { Promote actions that encourage the climate of } \\
\text { friendship and team spirit }\end{array}$ & 00 & 25 & 22.5 & 35 & 17.5 \\
\hline $\begin{array}{l}\text { Help out based on understanding other people's } \\
\text { needs and feelings }\end{array}$ & 00 & 22.5 & 32.5 & 30 & 15 \\
\hline Attentive to emotional cues and a good listener & 00 & 32.5 & 30 & 22.5 & 15 \\
\hline
\end{tabular}

Figure 17. Understanding customer's needs and match them to services or products

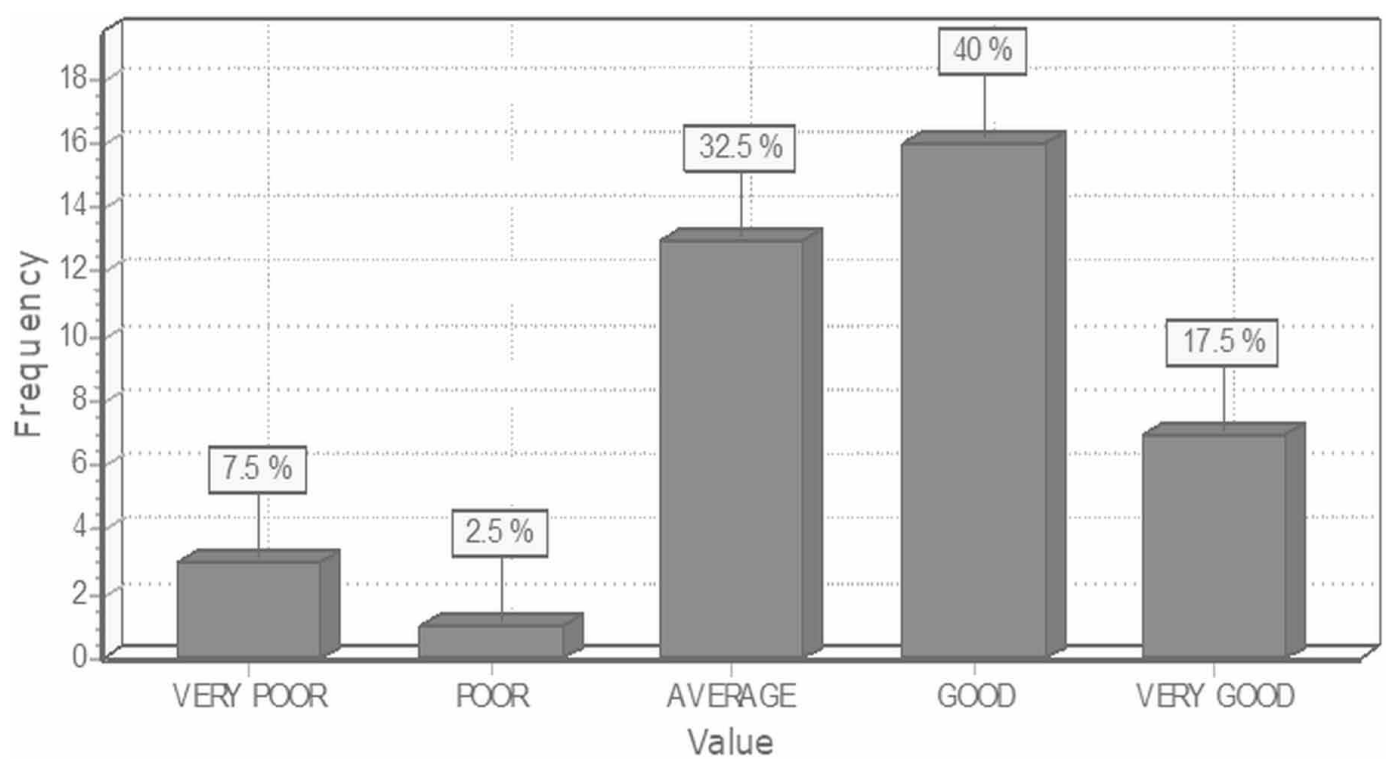

\section{Developing Others}

A good average number of participants shows that they acknowledge and reward people's strengths, accomplishments, and development (see figure 18).

\section{Change Management}

Table 8 shows the results on change management awareness the recognition of the need for change and removal of barriers.

\section{Diversity Management}

Diversity management awareness intelligence was also measured. Figure 19 shows that an average to a good number of employees respect and relate well to people from varied backgrounds and understand diverse worldviews and are sensitive to group differences. 
Figure 18. Acknowledging and reward people's strengths, accomplishments, and development

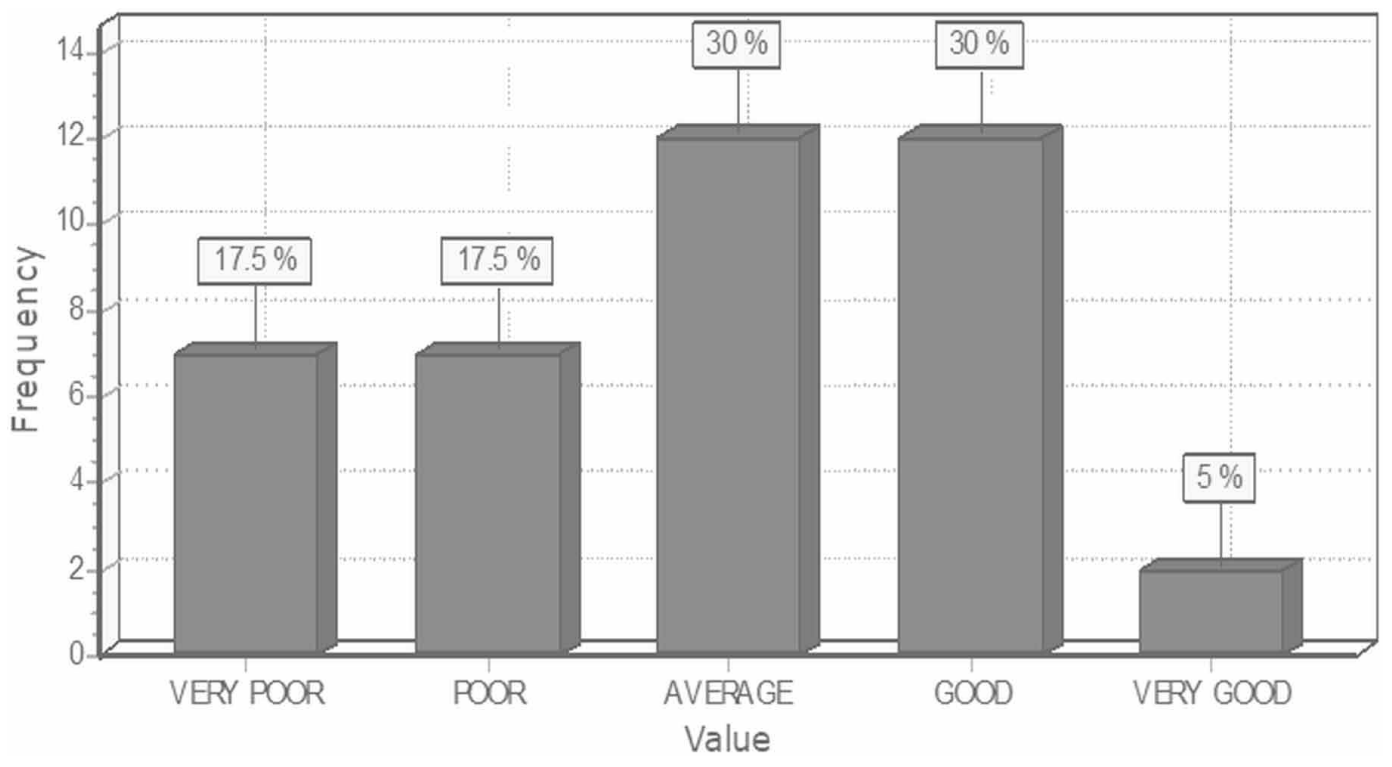

Table 8. Change management awareness

\begin{tabular}{|l|l|l|l|l|l|}
\hline \multirow{2}{*}{ Criteria } & \multicolumn{5}{c|}{ Percent Value of Response } \\
\cline { 2 - 6 } & \multicolumn{1}{c|}{ Very Poor } & \multicolumn{1}{c|}{ Poor } & \multicolumn{1}{c|}{ Average } & Good & Very Good \\
\hline $\begin{array}{l}\text { Recognize the need for change and remove } \\
\text { barriers }\end{array}$ & 00 & 30 & 17.5 & 37.5 & 15 \\
\hline $\begin{array}{l}\text { Acknowledge the need for change and challenge } \\
\text { the status quo }\end{array}$ & 2.5 & 27.5 & 15 & 40 & 15 \\
\hline $\begin{array}{l}\text { Champion the change and enlist others in its } \\
\text { pursuit }\end{array}$ & 10 & 17.5 & 37.5 & 27.5 & 7.5 \\
\hline Model the change expected of others & 00 & 17.5 & 47.5 & 25 & 10 \\
\hline
\end{tabular}

\section{Leadership}

Concerning leadership, results on leadership awareness are given in Table 9.

\section{Communication}

Concerning the communication aspect, as one that is a critical one for employee EI, it shows that the average number of employees are good at give-and-take and able to tune message according to the emotional cues they pick up. Further, the response value on communication, revealed that a very good number of employees foster open communication and stay receptive to bad news as well as good. Table109 provides the response value concerning communication.

\section{Implications}

This research is likely to be the first of its kind especially in the Namibian context where employee EI towards the improved job and organizational performance is analyzed. The study approach allowed and instigated the researcher to choose the best conceptualization of EI for the improved job and 
Figure 19. Respect and relate well to people from varied backgrounds

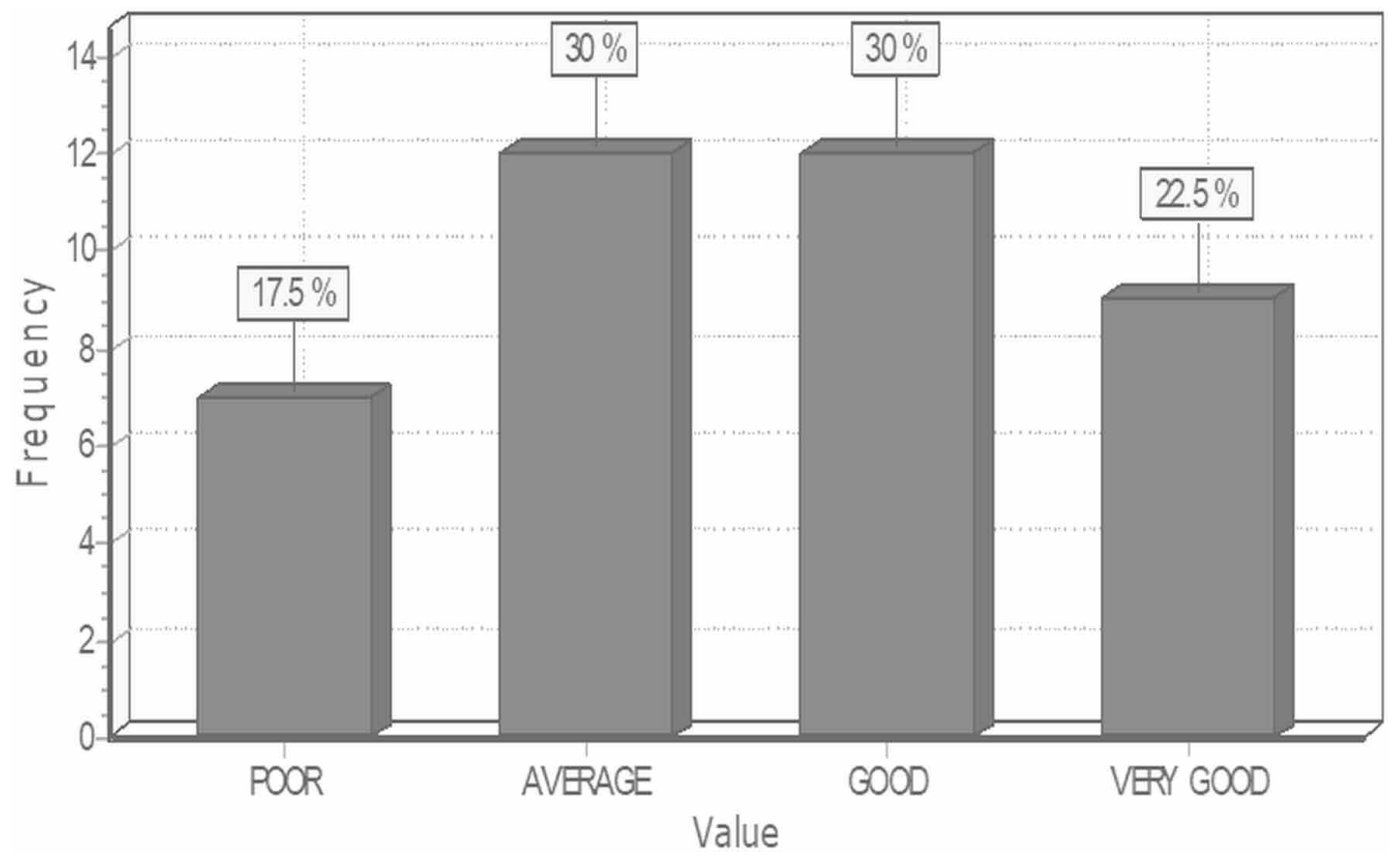

Table 9. Leadership awareness

\begin{tabular}{|l|l|l|l|l|l|}
\hline \multirow{2}{*}{ Criteria } & \multicolumn{5}{c|}{ Percent Value of Response } \\
\cline { 2 - 6 } & \multicolumn{1}{|c|}{ Very Poor } & \multicolumn{1}{c|}{ Poor } & \multicolumn{1}{c|}{ Average } & \multicolumn{1}{c|}{ Good } & Very Good \\
\hline $\begin{array}{l}\text { Respect and relate well to people from varied } \\
\text { backgrounds }\end{array}$ & 00 & 7.5 & 42.5 & 25 & 25 \\
\hline $\begin{array}{l}\text { Mentoring and coaching with challenging } \\
\text { assignments that grow a person's skill }\end{array}$ & 25 & 20 & 20 & 27.5 & 7.5 \\
\hline $\begin{array}{l}\text { Step forward to lead as needed, regardless of } \\
\text { position }\end{array}$ & 22.5 & 15 & 22.5 & 25 & 15 \\
\hline $\begin{array}{l}\text { Guide the job for organizational performance } \\
\text { with accountability }\end{array}$ & 22.5 & 17.5 & 22.5 & 25 & 12.5 \\
\hline
\end{tabular}

\section{Table 10. Communication}

\begin{tabular}{|l|l|l|l|l|l|}
\hline \multirow{2}{*}{ Criteria } & \multicolumn{5}{c|}{ Percent Value of Response } \\
\cline { 2 - 6 } & \multicolumn{1}{|c|}{ Very Poor } & \multicolumn{1}{c|}{ Poor } & \multicolumn{1}{c|}{ Average } & \multicolumn{1}{c|}{ Good } & \multicolumn{1}{c|}{ Very Good } \\
\hline $\begin{array}{l}\text { Good at give-and-take and able to tune according } \\
\text { to the emotional cues }\end{array}$ & 2.5 & 17.5 & 40 & 27.5 & 12.5 \\
\hline Deal with difficult issues straight forward & 7.5 & 27.5 & 25 & 22.5 & 17.5 \\
\hline $\begin{array}{l}\text { Listen well, seek mutual understanding and fully } \\
\text { welcome sharing of information }\end{array}$ & 5 & 20 & 20 & 35 & 20 \\
\hline $\begin{array}{l}\text { Foster open communication and stay receptive to } \\
\text { bad as well as good news }\end{array}$ & 7.5 & 20 & 22.5 & 17.5 & 32.5 \\
\hline
\end{tabular}


organizational performance. The outcomes of this research are expected to provide an informed and deeper understanding of the relationships between employee EI and job organizational performance, as well as the potential interaction effects of emotional self-awareness, self-confidence, self-assessment, self-control, responsibility, conscientious, adaptability, innovativeness, achievement drive., initiative, optimism, communication, among others. Such deeper knowledge may inform better decision-making and influence best business administration and management practices in an organization.

\section{FUTURE AREAS FOR RESEARCH}

A leader with this strength can articulate a vision or mission that resonates emotionally with both them and those they lead, which is a key ingredient in marshaling the motivation essential for going in a new direction (Goleman \& Boyatzis, 2017). Indeed, several studies have found a strong association between EI, driving change, and visionary leadership, but such studies in the Namibian context are few and hence need to be undertaken. Another interesting area would be frameworks and models of how in order to excel; leaders need to develop a balance of strengths across the suite of EI competencies. Future research can also explore the possibility of including a wide range of management and executive participation levels to obtain more insights on the influence of the cognitive and employee EI in an organization. Further studies must be undertaken which deliberately focus on the influence of sociodemographic variables on employee EI and performance be it individual or collective organizational performance. Comparative studies of employees' emotional intelligence across sectors, industries, and professional levels would also be interesting and provide deeper insight into training and development.

\section{RECOMMENDATIONS}

Based on research findings some of the recommendations include that NHE should consider first, assessing the job candidates' level of cognitive and EI when selecting people to fill job vacancies, especially management and executive positions. Equally significant is the understanding the interaction effects between the socio-demographic variables and predictor variables in predicting job performance to enhance organizational performance (Baporikar, 2020c; 2017b)). NHE as an organization must employ training for EI enhancement based on employees' appraisals and organizational needs.

\section{CONCLUSION}

Self-emotional awareness is the ability of individual to be understood about his/her emotions as well as ability to demonstrate such emotions. The second dimension related to the individual's ability to understand the emotions of others accurately perceiving and understanding of emotions has a significant influence on social interaction (Butt, Nisar, Nadeem, \& Baig, 2017). The current study contribute to literature of EI and organizational performance in many ways, First EI is positively associated with performance in work place and sheds light on the critical role of EI in enhancing organizational performance. Second the association between EI and employee behavior has been extensively explored. Results of current study support this assumption that EI is not only associated with work performance and career success, but also is related with employee behavior. So the results of current study broaden our understanding regarding EI and the scope of EI as well. Empirical findings also proved that EI level can be improved through EI training (McEnrue, Groves \& Shen, 2009). Findings from the current study are that there is a positive association between EI and organization performance so it can be argued that EI and organizational performance can be advanced through EI advancement. Further, social network strongly depend on EI (Mayer, 2008), EI training includes helping behavior, quality interaction, so it can be argued that proper EI training cross the organizational boundaries and effect personal lives as well. To conclude, it is reasonable to say that employee EI and 
personality can significantly influence individual job, performance, and organizational performance. That stated, it can also be concluded that EI can also be applied in the personnel space context and not only in the professional environment. Further, different levels of EI and personality will indicate different levels of job and organizational performance. Moreover, the understanding and knowledge of the concepts of EI and its influence on the collective organizational performance of employees may add value to the organization as employees become aware of the best practices. However, employee EI is a significant predictor of job collective organizational performance only if it is advocated and spearheaded properly in the organization. Finally, job collective organizational performance can be classified into the task and contextual performance.

\section{ACKNOWLEDGMENT}

The author acknowledges Ms. Wilhelmina Feris, MBA Graduate of HPGSB, Namibia University of Science and Technology, Namibia for contribution in data collection and analysis. 


\section{REFERENCES}

Ahmad, S., Nisar, Q. A., Othman, N., \& Kamil, B. A. M. (2017). Do emotional intelligence \& organizational politics influence the employee work behaviors and attitudes? Mediating role of political skill. Journal of Management, 51.

Baporikar, N. (2020a). Employees Outlook Regarding Quality and CRM Link for Enriched Competitive Strategy. [IJSEM]. International Journal of Sustainable Economies Management, 9(2), 27-47. doi:10.4018/ IJSEM.2020040103

Baporikar, N. (2020b). Logistics Effectiveness Through Systems Thinking. [IJSDA]. International Journal of System Dynamics Applications, 9(2), 64-79. doi:10.4018/IJSDA.2020040104

Baporikar, N. (2020c). Human Resource Management for Managing Cultural Diversity. [IJAMSE]. International Journal of Applied Management Sciences and Engineering, 7(1), 74-99. doi:10.4018/IJAMSE.2020010104

Baporikar, N. (2019). Perceptions re Community-Based Projects for Economic and Societal Development. [IJABE]. International Journal of Applied Behavioral Economics, 8(4), 35-60. doi:10.4018/IJABE.2019100103

Baporikar, N. (2018). Critical Success Factors for Executives in Global Economy. In A. Presenza \& L. Sheehan (Eds.), Geopolitics and Strategic Management in the Global Economy (pp. 40-56). IGI Global., doi:10.4018/9781-5225-2673-5.ch003

Baporikar, N. (2017a). Global Perspective on Talent Management: The South African Experience. In M. Mupepi (Ed.), Effective Talent Management Strategies for Organizational Success (pp. 283-300). IGI Global., doi:10.4018/978-1-5225-1961-4.ch018

Baporikar, N. (2017b). Organization Communiqué Effect on Job Satisfaction and Commitment in Namibia. [IJSSMET]. International Journal of Service Science, Management, Engineering, and Technology, 8(4), 19-41. doi:10.4018/IJSSMET.2017100102

Averill, J. R. (2007). Together again: Emotion and intelligence reconciled. Emotional intelligence: Knowns and unknowns, 49-71.

Bar-On, R. (1997). The Emotional Quotient Inventory (EQ-i): Technical manual. Multi-Health Systems.

Bharwaney, G. (2001). Emotionally Intelligent Living. Crown House Publishing Limited.

Bhattacharyya, M., \& Sengupta, N. (2007). EI myths or reality led. Excel Books.

Bowling, N. A. (2007). Is job satisfaction-job performance relationship spurious? A meta-analytic examination. Journal of Vocational Behavior, 71(2), 167-185. doi:10.1016/j.jvb.2007.04.007

Boyatizis, R. E. (1982). The competent manager: a model for effective Organizational Performance. Wiley.

Bozionelos, N., \& Singh, S. K. (2017). The relationship of emotional intelligence with task and contextual performance: More than it meets the linear eye. Personality and Individual Differences, 116, 206-211. doi:10.1016/j.paid.2017.04.059

Briner, R. (1999). The neglect and importance of emotion at work. European Journal of Work and Organizational Psychology, 8(8), 323-346. doi:10.1080/135943299398212

Brown, C., George-Curran, R., \& Smith, M. L. (2003). The role of EI in the career commitment and decisionmaking process. Journal of Career Assessment, 11(4), 379-392. doi:10.1177/1069072703255834

Brown, S. P., Cron, W. L., \& Slocum, J. W. Jr. (1997). Effects of goal-directed emotions on salesperson volitions, behavior, and Organizational Performance: A longitudinal study. Journal of Marketing, 61(1), 39-50. doi:10.1177/002224299706100104

Burnestein, A. (2014). How to Deal with Emotionally Explosive People (Revised Edition). McGraw Hill Press. Carmarthen, Wales.

Butt, S. S., Nisar, Q. A., Nadeem, S., \& Baig, F. (2017). Longitudinal study to examine the influence of emotional intelligence on organizational citizenship behavior: Mediating role of political skills. WALIA Journal, 33(1), $54-63$. 
Carmeli, A., \& Josman, Z. E. (2006). The relationship among EI, task performance, and organizational citizenship behaviors. Human Organizational Performance, 19, 403-419. doi:10.1207/s15327043hup1904_5

Cherniss, C., \& Goleman, D. (2001). The emotionally intelligent workplace. Jossey Bass.

Cherniss, C. (2001). EI and organisational effectiveness. In The emotionally intelligent workplace: How to select for, measure, and improve EI in individuals, groups. And organisations. San Francisco: Jossey-Bass.

Cherniss, C. (2015). The Emotionally Intelligent Workplace how to select, measure, and Improve EI in Groups. Jossey Bass Press.

Cobb, C. D., \& Mayer, J. D. (2000). EI: What the research says. Educational Leadership, 58(3), 14-18.

Darwin, C. (1872). The expression of the emotions in man and animals. University of Chicago Press. doi:10.1037/10001-000

Dhliwayo, P. (2018). The influence of cognitive intelligence, EI, and personality on job organizational performance: proposing a model for personnel selection. University of South Africa.

Diamond, E. (2010). The mindset to Master Self Awareness. Bloomington.

Furnham, A. (2012). EI - New Perspectives and Applications. InTech.

Ganji, M. (2011). Emotional Intelligence. Savalan.

Gardner, H. (1983). Frames of mind: The theory of multiple intelligences. Basic Books.

Goleman, D. (1995). Emotional Intelligence. Bantam Books.

Goleman, D. (1998). Working with Emotional Intelligence. Bantam Books.

Goleman, D. (2001). Emotional Intelligence: Issues in paradigm building. In C. Cherniss and D. Goleman (Ed's.) The Emotionally Intelligence Workplace. Jossey-Bass.

Goleman, D. (2014). Emotional Intelligence. Bloomsburg: Hill/IRWIN Inc.

Goleman, D., Boyatzis, R., \& McKee, A. (2002). Primal leadership: Realizing the Power of Emotional Intelligence. Harvard Business.

Goleman, D., \& Boyatzis, R. (2017). Emotional intelligence has 12 elements. Which do you need to work on. Harvard Business Review, 84(2), 1-5.

Gryn, M. (2010). The relationship between EI and job performance of call centre leaders. University of South Africa.

Gunkel, M., Schlaegel, C., \& Engle, R. L. (2014). Culture and a Cascading Model of EI: An Exploratory Analysis. In A. Verbeke, R. Van Tulder, \& S. Lundan (Eds.), Multinational Enterprises, Markets and Institutional Diversity (Vol. 9, pp. 229-257). Emerald Group Publishing Limited. doi:10.1108/S1745-886220140000009009

Hakkak, M., Nazarpoori, A., Mousavi, S. N., \& Ghodsi, M. (2015). Investigating the effects of emotional intelligence on social-mental factors of human resource productivity. Revista de Psicología del Trabajo y de las Organizaciones, 31(3), 129-134. doi:10.1016/j.rpto.2015.06.005

Higgs, M. (2004). A study of the relationship between EI and performance in the UK call centres. Journal of Managerial Psychology, 19(4), 442-454. doi:10.1108/02683940410537972

Hochschild, A. (1983). The Managed Heart: Commercialisation of Human Feeling. University of California Press.

Hoffmann, B. (2010). The relationship between Emotional Intelligence and leadership among middle managers in Namibia (Doctoral dissertation).

Jordan, P. J., Ashkanasy, N. M., \& Hartel, C. E. J. (2002). EI as a moderator of emotional and behavioural relations to job insecurity. Academy of Management Review, 27, 361-372. doi:10.5465/amr.2002.7389905

Joseph, D. L., \& Newman, D. A. (2010). EI: An integrative meta-analysis and cascading model. The Journal of Applied Psychology, 95(1), 54-78. doi:10.1037/a0017286 PMID:20085406 
Koman, E. S., \& Wolff, S. B. (2008). EI competencies in the team and team leader: A multi-level examination of the impact of EI on team Organizational Performance. Journal of Management Development, 27(1).

Lopes, P. N., Grewal, D., Kadis, J., Gall, M., \& Salovey, P. (2006). Evidence that EI is related to job performance and affect and attitudes at work. Psicothema, 18, 132-138. PMID:17295970

Low, G. N. (2013). Emotional Intelligence Achieving Academic and Career Excellence. Prentice-Hall Press.

Mandell, B., \& Pherwani, S. (2003). Relationship between EI and transformational leadership style: A gender comparison. Journal of Business and Psychology, 17(3), 387-404. doi:10.1023/A:1022816409059

Mankowitz, D. J. (2018). The African philosophical concept of Ubuntu as applied to the EI of adolescents: challenging the appropriateness of Western-derived concepts. University of South Africa.

Mayer, C. H. (2008). Managing conflict across cultures, values and identities: A case study in the South African automotive industry. Tectum-Verlag.

Mayer, J. D., \& Salovey, P. (1997). What is EI: Implications for educators? In P. Salovey \& D. Sluyter (Eds.), Emotional development, emotional literacy, and Emotional Intelligence (pp. 3-31). Basic Books.

McEnrue, M., Groves, K., \& Shen, W. (2009). Emotional intelligence development: Leveraging individual characteristics. Journal of Management Development, 28(2), 150-174. doi:10.1108/02621710910932106

Oaksford, M., Morris, F., Grainger, B., \& Williams, J. M. G. (1996). Mood, reasoning, and central executive processes. Journal of Experimental Psychology. Learning, Memory, and Cognition, 22(2), 476-492. doi:10.1037/0278-7393.22.2.476

Pekaar, K. A., Bakker, A. B., Van der Linden, D., \& Born, M. (2018). Self- and other focused EI: Development and validation of the Rotterdam EI Scale (REIS). Personality and Individual Differences, 120, 222-233. doi:10.1016/j.paid.2017.08.045

Petrides, K. V., Pita, R., \& Kokkinaki, F. (2007). The location of trait EI in personality factor space. British Journal of Psychology, 98, 273-289. doi:10.1348/000712606X120618 PMID:17456273

Piaget, J. (1936). Origins of intelligence in the child. Routledge \& Kegan Paul.

Rangriz, H., \& Mehrabi, J. (2010). The Relationship between EI, Organisational Commitment and Employees' performance in Iran. International Journal of Business and Management, 5(8), 50-55. doi:10.5539/ijbm.v5n8p50

Rexhepi, G., \& Berisha, B. (2017). The effects of emotional intelligence in employees performance. International Journal of Business and Globalisation, 18(4), 467-479. doi:10.1504/IJBG.2017.084351

Rushton, J. P., Murray, H. G., \& Paunonen, S. V. (1983). Personality, research creativity, and teaching effectiveness in university professors. Scientometrics, 5(2), 93-116. doi:10.1007/BF02072856

Serrat, O. (2017). Understanding and developing emotional intelligence. In Knowledge solutions (pp. 329-339). Springer. doi:10.1007/978-981-10-0983-9_37

Shafir, E., \& LeBoeuf, R. A. (2002). Rationality. Annual Review of Psychology, 53(1), 491-557. doi:10.1146/ annurev.psych.53.100901.135213 PMID:11752494

Shankman, M. L., Allen, S. J., Haber-Curran, P \& Komives, S. R. (2015). Emotionally intelligent leadership: A guide for students. Academic Press.

Sonnentag, S., Volmer, J., \& Spychala, A. (2008), Job Performance. In J. Barling \& C.L. Cooper (Eds.), The Sage Handbook of Organisational Behavior (Vol. 1, pp. 427-4470). Los Angeles, CA: SAGE. doi:10.4135/9781849200448.n24

Stone, J. R. (2008). Human Resource Management (5th ed.). John Wiley \& Sons.

Thorndike, E. L. (1920). Intelligence and its uses. Harper's, 140, 227-235.

Torubelli, V., \& Adeoye, H. (2011). EI and human relationship management as predictors of organizational commitment. IFE Psychological: An International Journal, 19(2), 212-226. 
Vigoda-Gadot, E., \& Meisler, G. (2010). Emotions in management and the management of emotions: The impact of emotional intelligence and organizational politics on public sector employees. Public Administration Review, 70(1), 72-86. doi:10.1111/j.1540-6210.2009.02112.x

Vrab, M, (2007). EI skills and leadership behavior in a sample of South African first-line managers. Management Dynamics, 16(2), 25-26.

Vygotsky, L. S. (1978). Mind in Society: Development of Higher Psychological Processes. Harvard University Press.

Weisinger, H. (1998). Emotional Intelligence in Business (Suleymangil). MNS Publishing.

Yazdani, Z., \& Riahi, Z. (2010). A survey of the relationship between emotional intelligence and performance of administrative units of Shiraz Medical Science University in 2010. The Mediaeval Journal, 3(3), 71-88.

Neeta Baporikar is currently Professor (Management) at Harold Pupkewitz Graduate School of Business (HPGSB), Namibia University of Science and Technology, Namibia. Prior to this, she was Head-Scientific Research, with the Ministry of Higher Education CAS-Salalah, Sultanate of Oman, Professor (Strategic Management and Entrepreneurship) at IIIT Pune and BITS India. With more than a decade of experience in the industry, consultancy, and training, she made a lateral switch to research and academics in 1995. Prof Baporikar holds D. Sc. (Management Studies) USA, Ph.D. in Management, the University of Pune INDIA with MBA (Distinction) and Law (Hons.) degrees. Apart from this, she is also an external reviewer, Oman Academic Accreditation Authority, Accredited Management Teacher, Qualified Trainer, Doctoral Guide and Board Member of Academics and Advisory Committee in accredited $B$-Schools. She has to her credit many conferred doctorates, is international and editorial advisory board member and reviewer for Emerald, IGI, Inderscience refereed journals, published numerous refereed research papers, and authored books in the area of entrepreneurship, strategy, management, and higher education. 